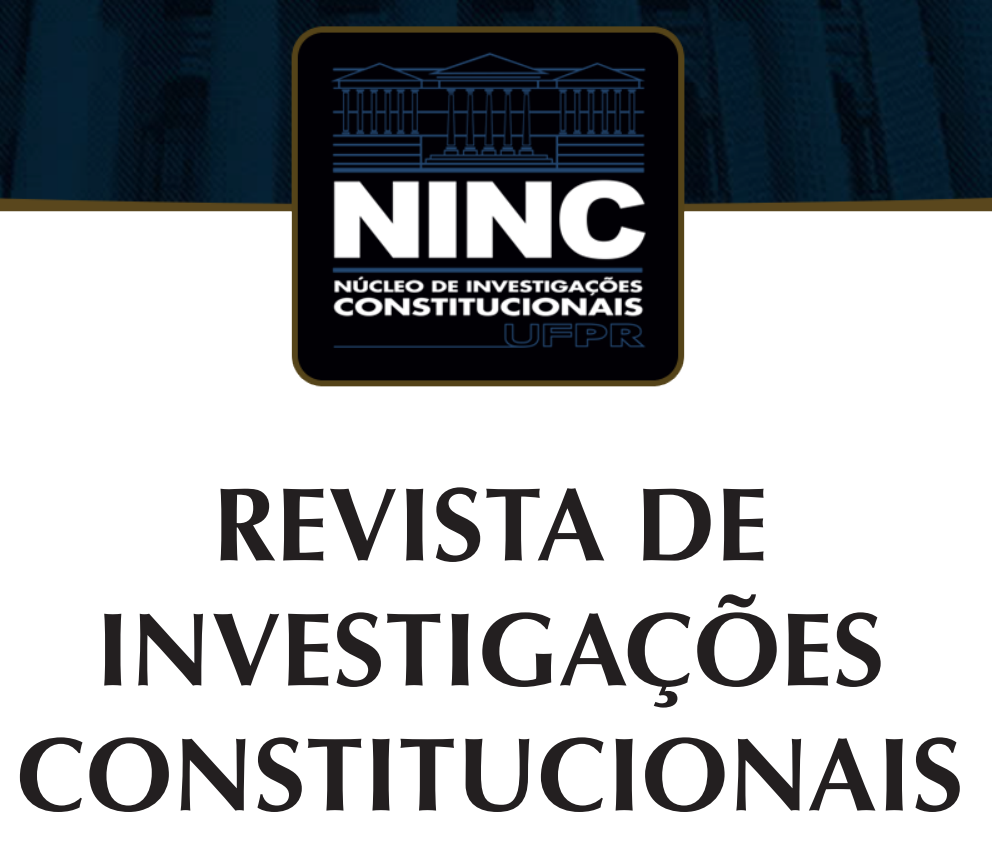

JOURNAL OF CONSTITUTIONAL RESEARCH

vol. 5 | n. 3 | setembro/dezembro 2018 | ISSN 2359-5639 | Periodicidade quadrimestral Curitiba | Núcleo de Investigações Constitucionais da UFPR | www.ninc.com.br 


\section{Social rights interpretation in Brazil and South Africa}

\section{Interpretação de direitos sociais no Brasil e na África do Sul}

\section{Abstract}

In this paper, I examine the social rights jurisprudence of Brazil and South Africa, two jurisdictions that have adopted markedly different approaches to their interpretation. In doing so, I advance three arguments relating to the study of social rights adjudication and the effects of the resulting jurisprudence. First, understanding the development of social rights jurisprudence requires understanding the pre-existing set of judicial norms that define the role of the judges and acceptable mode(s) of legal reasoning. Second, variations in institutional design and understandings of precedent means that one cannot assume that the decisions of the apex court will be universally or quickly incorporated into the decisions of the lower courts. As such, it may be necessary to look beyond apex court decisions to get an accurate picture of patterns of social rights jurisprudence in a given jurisdiction. Third, both of the dominant approaches have the potential to institgate significant policy change, but they also encourage different types of litigation and different litigants. This, in turn affects the approach taken to addressing the policy areas and does not necessarily lead to
Resumo

Neste artigo, examino a jurisprudência de direitos sociais do Brasil e da África do Sul, duas jurisdições que adotaram abordagens marcadamente diferentes para sua interpretação. Ao fazê-lo, adianto três argumentos relacionados ao estudo da judicialização dos direitos sociais e aos efeitos da jurisprudência resultante. Em primeiro lugar, entender o desenvolvimento da jurisprudência dos direitos sociais exige compreender o conjunto pré-existente de normas judiciais que definem o papel dos juízes e o(s) modo(s) aceitável(is) de raciocínio jurídico. Em segundo lugar, as variações no desenho institucional e nos entendimentos de precedente significam que não se pode presumir que as decisões do tribunal superior serão universal ou rapidamente incorporadas às decisões dos tribunais inferiores. Como tal, pode ser necessário olhar além das decisões judiciais ágeis para obter uma imagem precisa dos padrões da jurisprudência de direitos sociais em uma determinada jurisdição. Terceiro, ambas as abordagens dominantes têm o potencial de afetar mudanças políticas significativas, mas também encorajam diferentes tipos de litígios e litigantes diferentes. Isso, por sua vez, afeta a abordagem adotada para tratar das

Como citar esse artigo/How to cite this article: ROSEVEAR, Evan. Social rights interpretation in Brazil and South Africa. Revista de Investigações Constitucionais, Curitiba, vol. 5, n. 3, p. 149-183, set./dez. 2018. DOI: 10.5380/rinc.v5i3.60968.

* PhD Candidate at the Department of Political Science at University of Toronto (Toronto, Canada). E-mail: evan.rosevear@ utoronto.ca. I wish to thank Nicole Julie Fobe and Thiago Filippo Silva Jorge for their skillful assistance, the faculty staff of FGV Direito-Rio for providing not just funding but a home for much of the time that this research was conducted, and my 'Fellows in Rio' colleagues for their insights, assistance, and support. 
the prioritization of areas where the investment of state resources will yield the greatest returns or be the most socially just.

Keywords: social rights; Brazil; South Africa; jurisprudence; comparative constitutionalism. áreas de política e não leva necessariamente à priorização daquelas nas quais o investimento de recursos estatais produzirá os maiores retornos ou será o mais socialmente justo.

Palavras-chave: direitos sociais; Brasil; África do Sul; jurisprudência; constitucionalismo comparado.

\section{CONTENTS}

1. Introduction; 2. Constitutional Contexts and Patterns of Interpretation; 2.1. Brazil; 2.1.1. Health; 2.1.2. Education; 2.1.3. Housing; 2.2. South Africa; 2.2.1. Health; 2.2.2. Housing; 2.2.3. Education; 2.3 . Summary; 3. Explaining the Variation; 3.1. Judicial Culture; 3.1.1. Brazilian Judicial Culture; 3.1.2. South African Judicial Culture; 3.2. Institutional Design; 3.3. Summary; 4. Implications; 5. Conclusions; 6. References.

\section{INTRODUCTION}

Social rights-positive obligations on the state to provide for the maintenance and development of individuals independent of labor market participation-are now common, arguably standard, features of contemporary constitutions. At the beginning of $2016,58 \%$ of national constitutions included a justiciable right to education, $43 \%$ the right to health, and $27 \%$ the right to housing. Of the battery of eight social rights identified by Jung et al, ${ }^{1} 63 \%$ of constitutions contained at least one in justiciable form and $40 \%$ contained four or more. ${ }^{2}$ From their earliest entrenchment in the constitutions of Peru (1828), ${ }^{3}$ Germany (1919), ${ }^{4}$ and Argentina $(1949)^{5}$ to their international recognition via the Universal Declaration of Human Rights and the International Covenant on Economic, Social and Cultural Rights, social rights have become the focus of sustained popular, political, judicial, and academic attention.

The rights to child protection, education, health, social security, development, food and water, housing, and land. JUNG, Courtney; HIRSCHL, Ran; ROSEVEAR, Evan. Economic and Social Rights in National Constitutions, American Journal of Comparative Law, vol. 62, no. 4, p. 1043-1093, out. 2014.

2 JUNG, Courtney; HIRSCHL, Ran; ROSEVEAR, Evan. Justiciable and Aspirational ESRs in National Constitutions. In: YOUNG, Katherine G. (ed.) The Future of Economic and Social Rights. Cambridge: Cambridge University Press, 2019 (forthcoming). When both aspirational and justiciable variants are considered, 81\% of national constitutions contain the right to education, $70 \%$ the right to health, and $43 \%$ the right to housing; $83 \%$ contain at least one of the eight social rights, and $65 \%$ contain four or more.

3 Art. 171 of the Political Constitution of the Peruvian Republic, 1828. Cf. UNITED KINGDOM. Foreign Office. British and Foreign State Papers. Vol. 16. London: James Ridgway, 1828-1829. p. 966-88.

4 MARTIN, Charles E.; GEORGE, William Henry (eds). Consitution of Germany, 1919. In: Representative Modern Constitutions. MUNRO, William B.; HOLCOMBE, Arthur N. (Trad.) Los Angeles: Times-Mirror Press, 1923, p. 74-103, art. 161.

5 PEASLEE, Amos J. (ed.) Constitution of the Argentine Republic, 1949. In: Constitutions of Nations Concord. NH: Rumford, 1950, art. 7. 
Although a part of the "higher law" of countries marked by substantial religious, economic, social, and political variation, the formal articulation of these rights in constitutional documents is strikingly similar. Unsurprisingly, however, this similarity has not manifest in the similar interpretation and application of these rights by courts in different jurisdictions. Rather, two dominant approaches have emerged. ${ }^{6}$ The first is exemplified by Brazilian right to health jurisprudence. This approach treats social rights as (near) immediately realizable guarantees, owed by the state to specific individuals, the non-fulfilment of which is remedied by individual litigation resulting in inter partes decisions requiring the state to fund and/or provide specific medicines or medical services. ${ }^{7}$ The second is exemplified by the right to health and right to housing jurisprudence of the South African Constitutional Court. This approach is similar to an administrative law approach insofar as the primary focus of the analysis is on the "reasonableness" of government policy relevant to the provision of the social right(s) in question. ${ }^{8}$ Although a particular individual may not have received a benefit associated with a right, the courts were reluctant to step in if there is government policy in place that is deemed to be a reasonable means of progressively realizing that right.

In this paper, I examine the social rights jurisprudence of these two countries with an eye toward highlighting variation in their interpretation between both jurisdictions and rights, identifying factors responsible for the origin and perpetuation of this difference, and considering the implications thereof. In doing so, I advance three arguments relating to both the study of social rights adjudication and the effects of the resulting jurisprudence. First, in order to understand the development of social rights jurisprudence, it is essential to understand the pre-existing set of judicial norms that define the role of the judges and acceptable mode(s) of legal reasoning. Second, the cross-national diversity of judicial-institutional structures and mechanisms for advancing social rights claims means that one cannot automatically assume that the decisions of the apex court will be universally or quickly incorporated into the decision of the lower courts. As such, it may be necessary to look beyond apex court decisions to get an accurate picture of social rights jurisprudence in a given jurisdiction. Third, both of the dominant approaches have the potential to redistribute resources and instigate significant policy change. But, they also encourage different types of litigation and different litigants. This, in turn, shapes the incentives faced by policy-makers and does not

\footnotetext{
${ }^{6}$ Cf. BRINKS, Daniel M.; FORBATH, William. The Role of Courts and Constitutions in the New Politics of Welfare in Latin America. In: PEEREBOOM, Randall; GINSBURG, Tom (ed.). Law and Development of Middle-Income Countries: Avoiding the Middle-Income Trap. New York: Cambridge University Press, 2014.

${ }^{7}$ FERRAZ, Octavio Luiz Motta. The Right to Health in the Courts of Brazil: Worsening Health Inequities? Health and Human Rights, vol. 11, no. 2, p. 33-45, dec. 2009.

${ }^{8}$ LIEBENBERG, Sandra. South Africa: Adjudicating Social Rights Under a Transformative Constitution. In: LANGFORD, Malcolm (ed.) Social Rights Jurisprudence: Emerging Trends in International and Comparative Law. New York: Cambridge University Press, 2008.
} 
necessarily lead to the prioritization of areas where the investment of state resources will yield the greatest returns or be the most socially just.

The remainder of the paper is divided into four sections. In the next section I briefly outline the comparability of the cases before discussing the development of the right to health, education, and housing jurisprudence in both Brazil and South Africa. In Section 3, I argue that certain differences in the "judicial culture" of South Africa and Brazil, in combination with the institutional design of their respective judiciaries, substantially accounts for their divergent social rights jurisprudence. In Section 4, I discuss some of the observed and potential implications of the two interpretive approaches. I then offer concluding comments in Section 5.

\section{CONSTITUTIONAL CONTEXTS AND PATTERNS OF INTERPRETA- TION}

The Brazilian and South African experiences of social rights constitutionalism are well-suited to comparison. Their current constitutions came into being within a few years of one another, ${ }^{9}$ after periods of authoritarian rule, and were conceptualized as "peoples"' constitutions. They were also intended to bring about both symbolic and substantive transformation and to foster stable, inclusive democracies. In doing so they emphasized the importance of holding state actors accountable and defending individuals via the inclusion of extensive bills of rights and assigning their protection to strong, independent judicial branches. In the following two subsections, I briefly outline the development of the social rights jurisprudence in each country, emphasizing the rights to health, housing, and education.

\subsection{Brazil}

\subsubsection{Health}

The earliest litigation and the most prominent-in terms of volume, economic impact, and academic attention-in Brazil deals with health and access to healthcare. Claimant's legal arguments tend to be premised on some combination of the right to life (art. 5), the general guarantee of social rights (art. 6), the right to health (art.196), and the obligation of the state to provide a unified system of healthcare (art. 198) outlined in the Constitution along with Law 8080 of 1990, the public healthcare system's (Sistema Único de Saúde or SUS) enabling legislation and, in the case of HIV/ AIDS-related claims, Law 9313 of 1996 which mandates the free provision of antiretroviral medication.

\footnotetext{
9 Brazil's in 1988 and South Africa's in a two-stage process in 1993 (interim) and 1996 (final).
} 
For several years after the promulgation of the 1988 constitution the judiciary was largely unwilling to grant social rights claims. This initial reticence is attributable to two key factors: the conservatism of the senior, appellate judiciary and the professional norms of the judiciary as a whole that precluded transformative judgements in the area of social rights (or any other area of the law) without a coherent legal doctrine that could be used to justify granting such claims. Because there was no acceptable legal doctrine or interpretation of the social rights guarantees in the 1988 Constitution that would allow them to do so, regardless of their personal or professional desire to do so. As is the case for most countries in Latin America, Brazil has a long history of judicial review, although the willingness and ability of the judiciary to effectively deploy it has varied substantially in relation to the country's political climate. ${ }^{10}$ However, to the extent that the judges rendered decisions contrary to the will of the executive, the theoretical basis for the authority to do so was premised on liberal-democratic notions of negative rights such as the prevention of unlawful detention; existing doctrine was either ambivalent toward the positive components of rights obligations or antithetical to their justiciability.

In terms of legal reasoning, two principal arguments were initially successful against social rights claims with positive implications (e.g. the provision of medicines). The first argument was that these rights were programmatic rights; that they were not directly binding and required enabling legislation. If and when the legislature passed law or regulations to achieve these ends, the courts could legitimately decide on whether or not the State was meeting the obligations imposed by the legislature. Otherwise, the social rights were not directly applicable in the way that civil and political rights were. The second argument, also a classical constitutional objection, is based on the separation of powers doctrine. It is, so the argument goes, not the place of the courts to dictate policy to the executive and legislature. These two arguments, particularly the former, were generally held to be persuasive until the mid-1990s. As a result, there was little in the way of successful social rights litigation during this time. ${ }^{11}$

This approach began to change in the mid-1990s when decisions of the Rio Grande do Sul and São Paulo TJs (state appellate courts), as well as the STF (Brazil's apex court for constitutional matters) began to reject these arguments. ${ }^{12} \mathrm{~A}$ decision of particular note from the STF was Minister Celso de Mello's preliminary judgement,

\footnotetext{
${ }^{10}$ See e.g., MARCHANT, Anyda. The Brazilian Writ of Security (Mandado de Segurança) and Its Relationship to the Extraordinary Remedies of the Anglo-American Common Law: An Object Lesson in Latin American Law Making. Tulane Law Review, New Orleans, 19, 214 p. 1944-1945; and BREWER-CARÍAS, Allan R. Constitutional Protection of Human Rights. In: Latin America: A Comparative Study of the Amparo Proceeding. New York: Cambridge University Press, 2008, p. 142-147.

${ }^{11}$ SARLET, Ingo Wolfgang. Interview on 8 May 2015

12SARLET, Ingo Wolfgang. Interview on 8 May 2015.
} 
subsequently adopted unanimously by the plenary Court, in PET $1246 .{ }^{13}$ Originating in the State of Santa Catarina, the Court's decision required public funding for an experimental treatment administered in the U.S. for Duchenne muscular dystrophy, a degenerative disease affecting children. With respect to the justiciability of social rights, the key element of the decision is Minister de Mello's assertion that in choosing "between protecting the inviolability of the right to life, an inalienable Constitutional fundamental right, and a financial and secondary interest of the State, I believe-once this dilemma is established-ethical and legal reasons leave the judge with only one possible option: unwavering respect for life." ${ }^{14}$ Not all judges and not all courts were quick to follow, but a general rejection of the "separation of powers" and then the "programmatic rights" arguments seems to have become the consensus by about 1999. ${ }^{15}$

Early (successful) litigation focused on demanding public provision of medicines, predominantly antiretrovirals, to HIV/AIDS patients as a part of a loosely coordinated effort on the part of civil society organizations, health professionals and reformminded elements in government ministries and agencies. ${ }^{16}$ The form of the claims tended to run as follows: the claimant has a particular medical condition that puts their life or health at risk, a particular treatment or medicine would improve their health or chances of survival and, as such, the state has a responsibility to ensure they receive that treatment or medicine. In response, state parties tend to argue that judicial rulings in the area would violate the separation of powers, that there are reasonable protocols in place to allocate the health system's finite resources, that budgetary and legal limitations (e.g., the prohibition on the use of public funds for non-budgeted purposes) preclude the immediate provision of all treatments and medicines to all individuals and that the constitutional rights relating to health must be interpreted and applied as a

\footnotetext{
${ }^{13}$ Min. Celso de Mello, PET 1246 MC/SC (Medida Cautelar na Petição), 13-02-1997 D.J. (S.T.F. (Monocratic) 1997); Min. Sepúlveda Pertence, PET 1246 MC/SC, 17-04-1998 D.J. (S.T.F. (Plenary) 1997).

${ }^{14}$ WANG, Daniel. Courts as Healthcare Policy-Makers: The Problem, the Responses to the Problem and Problems in the Responses. Direito FGV Research Paper Series, São Paulo, Paper n. 75, p. 22, citing; Min. Celso de Mello, PET 1246 MC/SC (Medida Cautelar na Petição), 13-02-1997 D.J.

${ }^{15}$ In particular, the STJ maintained that the right to health was a programmatic right requiring legislation to attract justiciable obligations until 1999. SARLET, Ingo Wolfgang. Interview on 8 May 2015.

${ }^{16}$ PASSARELLI, Carlos André F.; and TERTO JÚNIOR, Veriano. Non-Governmental Organizations and Access to Anti-Retroviral Treatments in Brazil. Divulgação Em Saúde Para Debate, n. 27, p. 252-264, aug. 2003. p. 257; NUNN, Amy; DICKMAN, Samuel; NATTRASS, Nicoli; CORNWALL, Alexandra b; GRUSKIN, Sofia. The Impacts of AIDS Movements on the Policy Responses to HIV/AIDS in Brazil and South Africa: A Comparative Analysis. Global Public Health 7, n. 10, p. 1034-1038, nov. 2012; OLIVEIRA, Vanessa Elias; HOLDS, Lincoln Noronha. Judiciary-Executive Relations in Policy Making: The Case of Drug Distribution in the State of São Paulo. Brazilian Political Science Review, São Paulo, v. 5, n. 2, p. 10-38, jul. 2012; RICH, Jessica A. J. Grassroots Bureaucracy: Intergovernmental Relations and Popular Mobilization in Brazil's AIDS Policy Sector. Latin American Politics \& Society, [s.I.], v. 55, n. 2, p. 1-25, jun. 2013.
} 
part of the constitution as a whole, cognizant of the reality of finite resources and competing rights and interests. ${ }^{17}$

The fragmented nature of the Brazilian judicary, the limited utilization of fully electronic case management systems, and the inconsistency and incompatibility of case reporting systems means there is no precise picture of the volume or outcomes of these types of claims for the country as a whole. A large body of research focused on particular states, courts, treatments, or some combination of these, however, indicates that the volume of cases is quite high and that claimant success rates are extremely high. Early empirical work in this area found that claimants succeeded $82-100 \%$ of the time, with the majority of studies indicating success rates of more than $90 \% .{ }^{18}$ Although the methodology employed by most of these studies in the collection of data means that they cannot be, strictly speaking, considered to be representative samples, the congruence of the results is notable. These findings are also largely supported by more recent studies based on larger and more representative samples. For example, a 2013 study of right to health decisions of the State Appellate Courts (TJs) of Rio de Janeiro, Minas Gerais, and Pernambuco found an overall success rate of $97.8 \%,{ }^{19}$ another study in the State of Paraná found that cases filed in 2009 had success rate of $81 \%$ at the trial level and $92 \%$ at the appellate level. ${ }^{20}$ More recently, however, there is evidence of a slight decline in success rates. In a study of lawsuits seeking public provision of medicines filed in the Federal Court of the State of Paraná in 2014, the claimant success rate of those that had been resolved at the time of the study's publication was only $75 \% .^{21}$

\footnotetext{
${ }^{17}$ MARQUES, Silvia Badim; DALLARI, Sueli Gandolfi. Garantia Do Direito Social à Assistência Farmacêutica No Estado de São Paulo. Revista de Saúde Pública, vol. 41, n.1, p.101-107, 2007; HOFFMAN, Florian F.; BENTES, Fernando R. N. M. Accountability for Social and Economic Rights in Brazil. In: GAURI, Varun Gauri; BRINKS, Daniel M.(ed.). Courting Social Justice: Judicial Enforcement of Social and Economic Rights in the Developing World. New York: Cambridge University Press, 2008. p. 119-27; BORGES, Danielle; UGÁ, Maria Alicia Dominguez. Conflitos e impasses da judicialização na obtenção de medicamentos: as decisões de $1^{\text {a }}$ instância nas ações individuais contra o Estado do Rio de Janeiro, Brasil, em 2005. Cadernos de Saúde Pública, v. 26, no. 1, p. 60-62, jan. 2010.; MENICUCCI, Telma Maria Gonçalves; MACHADO, José Angelo. Judicialization of Health Policy in the Definition of Access to Public Goods: Individual Rights versus Collective Rights. trans. Leandro Moura. Brazilian Political Science Review, v. 4, no. 1, p. 48-49, jul. 2011.

${ }^{18}$ FERRAZ, Octavio Luiz Motta. Right to Health Litigation in Brazil, An Overview of the Research. Right to Health Through Litigation? Can Court Enforced Health Rights Improve Health Policy? Workshop, University Torquato di Tella, Buenos Aires, 2009.

${ }^{19}$ TRAVASSOS, Denise Vieira; FERREIRA, Raquel Conceição; VARGAS, Andréa Maria Duarte; MOURA, Rosa Núbia Vieira de; CONCEIÇÃO, Elza Maria de Araújo; MARQUES, Daniela de Freitas; FERREIRA, Efigênia Ferreira e. Judicialização da Saúde: Um Estudo de Caso de Três Tribunais Brasileiros. Ciência \& Saúde Coletiva, v. 18, no. 11, p.3419-3429. 2013.

${ }^{20}$ PEREIRA, José Gilberto; PEPE, Vera Lúcia Edais. Acesso a Medicamentos Por via Judicial No Paraná: Aplicação de Um Modelo Metodológico Para Análise e Monitoramento Das Demandas Judiciais. Revista de Direito Sanitario, v. 15, n. 2, p. 30-45. 2014.

${ }^{21}$ NISIHARA, Renato Mitsunori; POSSEBOM, Ana Carolina; BORGES, Luiza de Martino Cruvinel; SHWERTZ, Ana Claudia Athanasio; BETTES, Fernanda Francis Benevides. Judicial Demand of Medications Through the Federal Justice of the State of Paraná [Demanda Judicial de Medicamentos Na Justiça Federal Do Estado Do Paraná], Einstein, Sao Paulo, v. 15, n. 1, p. 85-91, mar. 2017.
} 
At the STF, Arguelhes and Hartmann identified 74 cases heard by one of the three collegiate bodies that dealt with the right to health on the merits of the case (as opposed to procedural matters) between 1988 and 2009. In all but one of these cases the state party was required to provide some or all of the requested medical treatment. ${ }^{22}$ The same study also found an almost non-existent engagement with the academic literature-either legal-doctrinal or social scientific — relating to positive rights and the nature of state obligations with respect to the realization of such rights.

In contrast, collective claims relating to the right to health are both rare and have met with very little success. For example, in their study of social rights litigation, Hoffman and Bentes identified 7,100 right to health cases decided by a sample of State Supreme Courts, ${ }^{23}$ the STF and the STJ between 1994 and $2004 .{ }^{24}$ Only 2\% of these were collective claims. Although Brazilian courts are perfectly willing to wholeheartedly involve themselves in healthcare issues when the claimant is an individual, in the context of collective claims this is very much not the case. Interestingly, and in direct contrast to the jurisprudence in individual claims, decisions in collective claims tend to invoke arguments about the scarcity of resources and the poor position of courts to second guess the decisions of health authorities as reasons to exercise restraint. ${ }^{25}$ In reference to the issue of collective claims, Ferraz concludes that,

The Brazilian judiciary... seems to be an obstacle to collective lawsuits in the field of health. There is a clear resistance, from their part, even when they grant the request of the plaintiff, to determine with any precision what the state is actually obliged to comply with. They are clearly more comfortable to issue more assertive and determined orders when the case is individual. ${ }^{26}$

Prado, in surveying right to health litigation trends, puts the matter more bluntly: "Brazil has a judiciary that is not open to collective claims."27

\footnotetext{
${ }^{22}$ ARGUELHES, Diego Werneck; HARTMANN, Ivar. A. Law in the Books and Books in the Court. Are Social Rights Literature and Judicial Practice on the same page in Brazil? Annuaire International des Droits de L'Homme. v. VII. Athens: Sakkoulas, 2014. p. 15-38.

${ }^{23}$ Those of Bahia, Goiás, Pernambuco, Rio de Janeiro, and Rio Grande do Sul.

${ }^{24}$ HOFFMAN, Florian F.; BENTES, Fernando R. N. M. Accountability for Social and Economic Rights in Brazil. In: GAURI, Varun Gauri; BRINKS, Daniel M.(ed.). Courting Social Justice: Judicial Enforcement of Social and Economic Rights in the Developing World. New York: Cambridge University Press, 2008. p. 115-19.

${ }^{25}$ WANG, Daniel. Courts as Healthcare Policy-Makers: The Problem, the Responses to the Problem and Problems in the Responses. Direito FGV Research Paper Series, São Paulo, Paper n. 75. p. 25-26.

${ }^{26}$ FERRAZ, Octavio Luiz Motta. Brazil: Are Collective Suits Harder to Enforce? In: LANGFORD, Malcolm; RODRIGUEZ-GARAVITO, Cesar; ROSSI; Julieta (ed.). Social Rights Judgments and the Politics of Compliance. Cambridge: Cambridge University Press, 2017. p. 189.

${ }^{27}$ PRADO, Mariana Mota. The Debatable Role of Courts in Brazil's Health Care System: Does Litigation Harm or Help? Journal of Law, Medicine \& Ethics, v. 41, n. 1, p. 124-137. 2013.
} 


\subsubsection{Education}

Right to education claims are primarily grounded in art. 208 of the 1988 Constitution, which dictates that the state has a duty to guarantee free and compulsory basic education as well as early childhood education and that "the Government's failure to offer compulsory education or offering it irregularly implies liability on the part of the competent authority." Litigation in this appears to have began in earnest in the early to middle 2000s, ${ }^{28}$ although the São Paulo State Public Ministry did file a number of cases dealing with education during the 1990s relating to age eligibility and catchment areas. ${ }^{29}$ Although there have been more collective cases filed in this area, individual claims are still the dominant form of action and the volume of litigation has been substantially lower than that of the right to health. ${ }^{30}$

A certain proportion of education cases have focused on access to institutions of higher education, but the bulk of claims, individual and collective, have dealt with primary and early childhood education. In the State of São Paulo, the Public Ministry successfully advanced a number of claims relating to daycare spaces in the early $2000 \mathrm{~s}$ in the State Court system, but the rulings were not particularly effective-the state was unable to provide the spaces as it lacked the resources. With respect to collective cases, the judiciary was largely unwilling to engage. According to one scholar and activist involved with Ação Educativa, an education focused NGO,

Judges would answer the individual claim and completely ignore the collective claim. For example, if we stated we needed 1,500 [daycare] places for children in the State of São Paulo, the Judge would say 'no can do, that is public policy.' But, if we asked for a single place for a child, this was not seen as a problem. ${ }^{31}$

Similarly, a Public Defender engaged in right to housing litigation noted that in advancing collective claims, Public Defenders (and others) face a lot of judicial resistance, often in the form of references to the reserva possivel, the separation of powers, and concerns about judicial activism in order to deny collective claims.

This, in turn, has led many, including the Public Defender's Office, to focus predominantly on individual claims. The principal concern with individual litigation in the

\footnotetext{
${ }^{28}$ SARLET, Ingo Wolfgang. Interview on 8 May 2015; PIOVESAN, Flavia, Brazil: Impact and Challenges of Social Rights. in the Courts. In: LANGFORD, M. (ed.). Social Rights Jurisprudence: Emerging Trends in International and Comparative Law. Cambridge: Cambridge University Press, 2009. p. 188-89.

${ }^{29}$ SILVA, Caitia Aida. Brazilian Prosecutors and the Collective Demands: Bringing Social Issues to the Courts of Justice. Miami: Latin American Studies Association Annual Meeting, 2000.

${ }^{30}$ PIOVESAN, Flavia, Brazil: Impact and Challenges of Social Rights. in the Courts. In: LANGFORD, M. (ed.). Social Rights Jurisprudence: Emerging Trends in International and Comparative Law. Cambridge: Cambridge University Press, 2009. p. 188-89; RASCOVSKI, Luiz. Interview on 23 Apr. 2015 (trans. Nicole Julie Fobe); XIMENES, Salomão Barros. Interview on 24 Apr. 2015 (trans. Nicole Julie Fobe).

${ }^{31}$ XIMENES, Salomão Barros. Interview on 24 Apr. 2015 (trans. Nicole Julie Fobe).
} 
area of education is that rather than resulting in policy change, it has simply led to parallel lists. In general, all primary and pre-primary institutions have waiting lists. When a judge orders the executive to provide a place to a specific individual, all that happens is that they are given a priority status on the waiting list. ${ }^{32}$ More recently, however, there has been a notable success in the area of collective education claims. In December of 2013 the São Paulo State Court of Appeal (SPTJ), overturning the trial decision, ruled that the City of São Paulo was required to make 150,000 new child care spots available by $2016 .^{33}$ This decision was the result of several years combined efforts of the Public Ministry, Public Defender's Office, Ação Educativa, and other NGOs. One of the key distinguishing features of the case was the amount of research and data presented by the claimants that clearly identified underserviced areas and gaps in coverage at a level of detail not previously seem. ${ }^{34}$ At present, however, the implementation of this decision and whether it will act as a guide for subsequent claims is unclear.

\subsubsection{Housing}

In contrast to right to health and right to education litigation, the right to housing is generally invoked as a shield rather than a sword in Brazil. That is, it is most frequently used as a defense against eviction orders rather than an attempt to exact a good or benefit directly from the state. Right to housing litigation also appears to be the least commonly advanced and to have had the least impact of the three rights. ${ }^{35}$ At least part of the reason for this is attributable to the seeming unwillingness of the judiciary to directly abrogate individual property rights. ${ }^{36}$ That said, as a general rule, a primary residence that has been used as collateral against a loan cannot be seized on the basis of a right to housing. ${ }^{37}$ Additionally, in the lower courts, eviction orders have be known to be accompanied by temporary provision of a stipend to the evicted party in an amount deemed sufficient to pay for alternative accommodation. In practice, however, this does not generate additional housing or security of tenure, but simply

32 RASCOVSKI, Luiz. Interview on 23 Apr. 2015 (trans. Nicole Julie Fobe); XIMENES, Salomão Barros. Interview on 24 Apr. 2015 (trans. Nicole Julie Fobe).

33 VIERA, Oscar Vilhena. Judicial Experimentation and Public Policy: A New Approach to the Right to Education in Brazil. OxHRH Blog, 31 July 2014. Available at: <http://ohrh.law.ox.ac.uk/?p=12688>.

${ }^{34}$ XIMENES, Salomão Barros. Interview on 24 Apr. 2015 (Trans. Nicole Julie Fobe).

${ }^{35}$ COUTINHO, Maria Laura. Do Brazilian Courts Contribute to the Implementation of the Right to Housing? Fundação Getulio Vargas - Research Paper Series, São Paulo, Feb. 2014; SCHULZE, Martin. Interview on 07 May 2015 (trans. Fábio Tomkowski).

${ }^{36}$ AUGUSTO, André. Interview on 24 Apr. 2015 (trans. Nicole Julie Fobe); MÉSZÁROS, George. Social Movements, Law, and the Politics of Land Reform: Lessons from Brazil, Law, Development and Globalization. Abingdon: Routledge, 2013. p. 4-5.

${ }^{37}$ SARLET, Ingo Wolfgang. Interview on 8 May 2015. 
results in the evictee moving into different irregular housing where they remain exposed to the same precarity. ${ }^{38}$

Despite some victories in the trial courts-which have been overturned on appeal-and a certain willingness to experiment by progressive judges, scholars such as Mészáros suggest that there is a heavy strain of conservatism present in the Brazilian judiciary that is associated with the enforcement of liberal conceptions of private property and equates attempts to modify that understanding (e.g., through protest), as attacks on the rule of law. This approach has a chilling effect on land reform as it introduces a variety of procedural requirements, increases the cost of expropriation, and plays into a narrative of occupiers as threatening the rule of law. ${ }^{39}$

\subsection{South Africa}

\subsubsection{Health}

The right to health was also the first social right to attract judicial attention in South Africa. ${ }^{40}$ The parameters of the right are laid out in section 27 of the 1996 Constitution which stipulates that everyone has the right to, inter alia, "access to health care services, including reproductive health care," requires the state to progressively realize the guarantee via "reasonable legislative and other measures within its available resources," and unqualifiedly asserts that "No one may be refused emergency medical treatment."

The first major case was brought by Mr. Soobramoney, a 41-year-old diabetic man with chronic renal failure as well as a number of other serious medical issues who had been denied the dialysis necessary for his continued survival. The resources of the renal clinic in question - the only one in the province-were limited and it was only able to provide dialysis to $30 \%$ of those requiring it. In response, the clinic had employed nation-wide guidelines to prioritize access to treatment for those with the best prospects of recovery. The applicant did not meet these criteria and sought an order from the High Court requiring the clinic to provide treatment.

In the High Court decision, Justice Combrinck determined that the Clinic had insufficient resources to treat all those requiring it, that the guidelines were not unreasonable, and that it was "not the function of this Court to direct the State to make

\footnotetext{
${ }^{38}$ VALLE, Vanice Regina Lírio do. Judicial adjudication in housing rights in Brazil and Colombia: a comparative perspective. Revista de Investigações Constitucionais, Curitiba, vol. 1, n. 2, p. 67-102, maio/ago. 2014. DOI: http://dx.doi.org/10.5380/rinc.v1i2.40511. p. 89.

${ }^{39}$ MÉSZÁROS, George. Social Movements, Law, and the Politics of Land Reform: Lessons from Brazil, Law, Development and Globalization. Abingdon: Routledge, 2013.

${ }^{40} \mathrm{Cf}$. Van Biljon and Others v. Minister of Correctional Services and Others, [1997] 4 S.A. 441 ((C) 1997).
} 
additional funds available to the renal clinic so that the applicant and others may be treated" as that was a fundamentally political decision. ${ }^{41}$ Justice Combrinck also rejected the argument that the fact that the claimant would die without dialysis meant that this constituted an emergency situation. As such, he dismissed the application.

The decision was appealed to the Constitutional Court, which upheld the decision of the High Court. In so doing, Chief Justice Chaskalson also affirmed Justice Combrinck's determination that it was not the place of the courts to interfere with the state's allocation of resources. In light of the depth and diversity of need, he held, the state was required to make difficult decisions and in doing so "There will be times when this requires it to adopt a holistic approach to the larger needs of society rather than to focus on the specific needs of particular individuals within society." ${ }^{42}$ The Soobramoney decision was a great disappointment to many human rights advocates, academics, and civil society organizations, many of whom who viewed the courts' refusal to examine the reasonableness of the allocation of funding as an abdication of their responsibility. ${ }^{43}$

The second major right to health case dealt with by the Constitutional Court was Treatment Action Campaign, ${ }^{44}$ five years later. Rather than the availability of a service to a particular individual, TAC challenged the adequacy of government measures to address mother-to-child transmission of HIV. Specifically, the organization argued that restricting the distribution of Nevirapine, an antiretroviral drug, to a limited number of test sites was unreasonable in light of its previously demonstrated effectiveness and the fact that the state was receiving the drug at no cost. It also argued that the lack of a national plan for the prevention of mother-to-child transmission was a violation of its duty to progressively realize the right to health through legislative and other means. ${ }^{45}$ In response, the state argued that it did not have the resources to provide the full package of care it intended to provide with the drug at other location and that excessive distribution in the absence of that full package, might lead to decreased long-term efficacy and also presented a safety issue. ${ }^{46}$

In its decision, the Court held that the social rights in the constitution could not be construed so as to enable everyone to immediately demand the UN Minimum Core. Rather, they stipulated that government policy need only to reasonably seek to progressively bring about those rights and that courts were limited at best arbiters of

\footnotetext{
${ }^{41}$ Soobramoney v. Minister of Health (KwaZulu-Natal), [1998] 1 S.A. 430 ((D) 1997) para. 438.

${ }^{42}$ Soobramoney v. Minister of Health (KwaZulu-Natal), 1997 ZACC 17 ((C) 1997) para. 32.

${ }^{43}$ See e.g., SARKIN, Jeremy. Health. South African Human Rights Yearbook, vol. 8, p. 101-103, 1998; SCOTT, Craig; ALSTON, Philip. Adjudicating Constitutional Priorities in a Transnational Context: A Comment on Soobramoney's Legacy and Grootboom's Promise. South African Journal on Human Rights, vol. 16, 2000. p. 268.

${ }^{44}$ Minister of Health and Others $v$ Treatment Action Campaign and Others (No. 2), ZACC 15 (South Africa 2002) [hereinafter "TAC"].

${ }^{45} \mathrm{TAC}$, para. 10.

${ }^{46} \mathrm{TAC}$, paras. $51-4$.
} 
policy decisions. ${ }^{47}$ While denying its ability to make policy, the Court asserted its authority to compel the state to act, holding that it was not a violation of separation of powers to compel adherence through injunction. Ultimately, the Court declared that the withholding of the drug was unreasonable, as the policy in place failed to provide a potentially lifesaving drug which could have been administered with little or no cost to the state. ${ }^{48}$ The government was ordered to remove the restrictions on the drug and facilitate its use, and "take reasonable measures" to extend counselling and testing facilities in hospitals. Although a number of human rights commentators were troubled by the Court's rejection of the UN Minimum Core approach, ${ }^{49}$ this case was widely seen as (correctly) walking back the level of deference accorded the state in the area of healthcare and a promising continuation of the pattern it set in its landmark housing decision in 2000.

\subsubsection{Housing}

Although the right to health was the first social right engaged with by the Constitutional Court, it is the right to housing, largely relating to constitutionality of evictions, that has constituted the bulk of its attention in this area. The first of these cases came in $2000 .{ }^{50}$ In the Grootboom decision, the Court established the basis of its current "reasonableness" approach to the interpretation and application of South Africa's constitutionalized social rights. The case concerned the residents of an informal settlement near Cape Town who were forcibly evicted and sought relief via the courts. In its decision, the Court recognized that state capacities are inherently limited and that immediate realization of rights such as the right to housing is not always possible. Rather, what is required is that the state pursues "reasonable" measures to give effect to those rights. The key element of the decision, however, was that the Court also indicated that if the state failed to do so, courts can and must enforce these obligations. The Court also provided some degree of guidance with respect to the parameters of reasonable: if measures taken fail to make provision for providing for the needs of the most desperate, the Court held, they may not pass the test of reasonableness. ${ }^{51}$ As the government's extant programs failed to make provision for temporary relief for the most disadvantaged, the Court issued a declaratory order requiring the state to devise and implement a program which provided relief (in terms of shelter) for the most desperate.

\footnotetext{
${ }^{47}$ TAC, ZACC paras. $26,34-8$.

${ }^{48}$ TAC, ZACC para. 80.

${ }^{49}$ See e.g., BILCHITZ, David. Towards a Reasonable Approach to the Minimum Core: Laying the Foundations for Future Socio-Economic Rights Jurisprudence. South African Journal on Human Rights, vol. 19, 2003.

${ }^{50}$ Government of the Republic of South Africa and Others v Grootboom and Others, [2000] ZACC 19 (South Africa 2000) [hereinafter "Grootboom"].

${ }^{51}$ Grootboom, [2000] ZACC para. 44.
} 
In subsequent cases, the decision to grant an eviction order has revolved around judicial consideration of whether, in the opinion of the court, "it is just and equitable to do so, after considering all the relevant circumstances." ${ }^{52}$ As per the governing statute, these circumstances include whether land has been or can reasonably be made available by the state for the relocation of the evictees and the likely impact on groups, such as children and households headed by women, attracting special consideration. ${ }^{53}$ In this jurisprudence, the courts have emphasized the importance of meaningful engagement and consultation regarding the development of housing policies, ${ }^{54}$ the primary responsibility of the municipalities to provide alternative accommodation, ${ }^{55}$ and the fact that the right to housing could justify temporarily limiting individuals' property rights where eviction could lead to homelessness. ${ }^{56}$ Relatedly, the courts have also established that unreasonable delay on the part of the state in finding alternative accommodations or otherwise settling the issue with the property owner could attract "constitutional damages." ${ }^{157}$ At the same time, the Courts have consistently maintained that they cannot be directly involved in the crafting of policy. Rather, the courts have restricted themselves to a largely procedural role, ensuring that the processes used to arrive at decisions take into consideration all relevant factors and that the decisions taken and actions based on those decisions are reasonable and taken in a timely fashion.

\subsubsection{Education}

In contrast to Brazil, the right to education has not been the subject of a significant body of litigation. The small volume of cases that have been considered dealt with the broad parameters of the right, including whether tertiary education was included (it is not), and various issues relating to language of instruction. ${ }^{58}$ This is somewhat

\footnotetext{
52 "Prevention of Illegal Eviction from and Unlawful Occupation of Land Act 19 of 1998" (1998) s.4(7); see also, "Constitution of South Africa" (1996) s.26(3); the remainder of this discussion draws heavily on WILSON, Stuart; CLARK, Michael. Evictions and Alternative Accommodation in South Africa 2000-2016: An Analysis of the Jurisprudence and Implications for Local Government. 2. ed. Johannesburg: Socio-Economic Rights Institute of South Africa, 2016.

${ }^{53}$ Prevention of Illegal Eviction from and Unlawful Occupation of Land Act 19 of 1998 preamble; e.g., Port Elizabeth Municipality v Various Occupiers, [2004] ZACC 7 (2004) para. 30.

${ }^{54}$ Residents of Joe Slovo Community, Western Cape v Thubelisha Homes and Others, ZACC 16 (CC 2009) paras 302-3, 378.

${ }^{55}$ Blue Moonlight Properties 39 (Pty) Limited v Occupiers of Saratoga Avenue and Another, [2010] ZAGPJHC 4 (2010) paras. 42-7, 57.

${ }^{56}$ Occupiers of Skurweplaas v PPC Aggregate Quarries, [2011] ZACC 36 (2011) para. 23; City of Johannesburg Metropolitan Municipality v Blue Moonlight Properties 39 (Pty) Ltd and Another, [2011] ZACC 33 (2011) paras. 16-18.

${ }^{57}$ Modder East Squatters and Another v Modderklip Boerdery (Pty) Ltd, President of the Republic of South Africa and Others v Modderklip Boerdery (Pty) Ltd, [2004] ZASCA 47 (2004) paras. 41-43.

${ }^{58}$ M SELEOANE, Mandla. Socio-Economic Rights in South Africa: Theory and Practice Pretoria: Human Sciences Research Council, 2001. p. 48-52; MCCONNACHIE, Cameron; MCCONNACHIE, Chris. Concretising the Right
} 
surprising in light of the serious issues facing South Africa's basic education system. There are numerous examples of effective and well-organized publicly-funded schools in South Africa, including in areas affected by poverty. They are not, however, the norm. Key issues include lack of basic infrastructure and services such as libraries, computers, clean water, and electricity, well-trained teaching staff, and effective administrators. ${ }^{59}$ Over the past few years, however, a few issues relating to the right have been considered by the Courts. ${ }^{60}$ For example, in 2015 the Supreme Court of Appeal held that "that s 29(1)(a) of the Constitution entitles every learner at public schools in Limpopo to be provided with every textbook prescribed for his or her grade before commencement of the teaching of the course for which the textbook is prescribed" and that it was the responsibility of the provincial and National Departments of education to do so. ${ }^{61}$ At present, however, recent nature of the cases would make a sustained discussion of the jurisprudence or its effectiveness largely speculative.

\subsection{Summary}

In Brazil, litigation was initially concentrated in the area of the right to health - in particular the provision of pharmaceuticals. Although education claims-also largely individual-have increased significantly in the past decade, the right to health remains the focus. In contrast, the right to health was the initial focus of social rights litigation in South Africa, but it was quickly surpassed by right to housing claims, primarily dealing with the opposition to eviction orders for those residing in informal settlements.

With respect to the right to health in particular, the Brazilian judiciary after a period of experimentation and uncertainty relating primarily to whether or not anything beyond a declarative judgment could be issued where the state was found to have violated an individual's right to health, adopted an individualized approach to the adjudication of the right to health that demanded immediate realization. In contrast, in its first social right case, Constitutional Court of South Africa expressly rejected the idea that the right to health provided for in the South African Constitution could confer immediately realizable obligations, even in the face on imminent death (Soobramoney).

to a Basic Education. South African Law Journal, vol. 129, 2012. p. 555-556..

${ }_{59}$ MNCUBE, Vusi S.; MADIKIZELA-MADIYA, Nomanesi. South Africa: Educational Reform - Curriculum, Governance and Teacher Education. In: HARBER, Clive (Ed.). Education in Southern Africa. London: Bloomsbury Academic, 2013. p. 177-79; see also, Nic SPAULL, Nicholas. South Africa's Education Crisis: The Quality of Education in South Africa 1994-2011. Johannesburg: Centre for Development and Enterprise, 2013; BADAT, Saleem; SAYED, Yusuf. Post-1994 South African Education: The Challenge of Social Justice. The ANNALS of the American Academy of Political and Social Science, vol. 652, no. 1, p. 127-148, 2014; DONOHUE, Dana; BORNMAN, Juan. The Challenges of Realising Inclusive Education in South Africa. South African Journal of Education, vol. 34, no. 2, p. 01-14, June 2014.

${ }^{60}$ See, e.g. MCCONNACHIE, Cameron; MCCONNACHIE, Chris. Concretising the Right to a Basic Education. South African Law Journal, vol. 129, 2012.

${ }^{61}$ Minister of Basic Education v Basic Education for All (December 5, 2015). 
Subsequent litigation of social rights relied on organizations (for example, Treatment Action Campaign) or representatives of a larger, well-defined group (e.g. Mrs. Grootboom).

\section{EXPLAINING THE VARIATION}

While the explanation for the divergent jurisprudence in these two jurisdictions is assuredly a complex, involving reference to a variety of social, political, and economic factors. Two interrelated legal-institutional factors appear to have contributed significantly. The first of these is the distinctive "judicial cultures" of the two countries and the second is the design of their judicial institutions, particularly the mechanisms available for advancing rights claims.

\subsection{Judicial Culture}

At one extreme, the formalist understanding of judicial decision-making - to the extent that judicial review is deemed acceptable practice-conceives of rights interpretation as the application doctrine to legal problems by experts in the process in a manner that does not require reference to extra-legal material. ${ }^{62}$ Critics of this approach have long argued that understanding law in this way is descriptively naïveparticularly with regard to its ability to account for structural bias-and prescriptively improbable, if not impossible. The attitudinal approach, on the other extreme, characterizes judicial decision-making as an exercise in the post-hoc rationalization of judges' personal preferences. This approach has been critiqued as overly cynical and accused of absurdly attributing legal decisions to "what the judge had for breakfast." ${ }^{\prime 3}$ As with many academic debates, however, the bulk of the evidence suggests that the answer lies somewhere in the middle and the extremes are rarely, if ever, observed.

In practice, judges do appear to take principles and doctrine seriously, but even within particular legal communities there is an overwhelming tendency toward heterogeneity in their definition. In this vein, the idea of jurisdictionally-specific judicial

\footnotetext{
62 The ideal-type legal formalism in this sense is the "classical legal orthodoxy" of Christopher Columbus Langdell. Th GREY, Thomas C. Langdell's Orthodoxy. University of Pittsburgh Law Review, vol. 45, 1983. p. 6. ("Classical orthodoxy was a particular kind of legal theory-a set of ideas to be put to work from inside by those who operate legal institutions, not a set of ideas about those institutions reflecting an outside perspective, whether a sociological, historical or economic explanation of legal phenomena.").

${ }^{63}$ Although the origins of this phrase are somewhat unclear it relates to the work of the American Legal Realists, particularly that of Jerome Frank. See, e.g. SCHAUER, Frederick. Thinking Like a Lawyer: A New Introduction to Legal Reasoning Cambridge: Harvard University Press, 2009. p. 129. Humorous but for its implications, there is some evidence the judges' breakfasts do have an impact on their decisions, although the key element appears to be when they had them rather than what they had. DANZIGER, Shai; LEVAV, Jonathan; AVNAIM-PESSO, Liora. Extraneous Factors in Judicial Decisions. Proceedings of the National Academy of Sciences, vol. 108, no. 17, Apr. 2011. p. 6889-92.
} 
"logics of appropriateness" may offer insight into behaviour of judges. ${ }^{64}$ Premised on a sociological understanding of institutions, at the core of this approach is the proposition that,

Rules are followed because they are seen as natural, rightful, expected, and legitimate. Actors seek to fulfill the obligations encapsulated in a role, an identity, a membership in a political community or group, and the ethos, practices and expectations of its institutions. Embedded in a social collectivity, they do what they see as appropriate for themselves in a specific type of situation. ${ }^{65}$

The implication is that individual behaviour is often guided by what the actor thinks - on the basis of the values and norms they have internalized-is the "right" thing to do in a given situation. In line with this messier understanding of behaviour, a number of scholars have identified judges' internalized norms about the appropriate role of courts in a political system as a key determinant of their decision-making. ${ }^{66}$

Of particular note is Hilbink's argument that the Chilean judiciary's internalized distinction between legal and political matters enabled them to reconcile their understanding of the judicial role with their compliance with the Pinochet regime. By asserting that objections to the regime were political matters, and therefore external to the legal system, judges were able to frame them as beyond their purview. ${ }^{67}$ The logical extension of this line of reasoning suggests that the judicial interpretation of constitutional rights -including social rights - will be strongly shaped by a jurisdiction's "judicial culture." Put differently, allowing for variation among individual judges, a combination of socialization-via shared educational and professional experiences-and selectionvia the hiring and promotion of individuals who have internalized the values and beliefs of their superiors-will result in a set of more or less commonly held beliefs about acceptable and unacceptable modes of legal reasoning in a given jurisdiction. ${ }^{68}$ In combination with similarly shaped ideas about the appropriate role of judges and the role

\footnotetext{
${ }^{64}$ Albeit at the price of parsimony.

${ }^{65}$ MARCH, James G.; OLSEN, Johan P. The Logic of Appropriateness. Arena - Centre for European Studies Working Papers, Paper n. 04/09, 2004. Available at: <https://www.sv.uio.no/arena/english/research/publications/arena-working-papers/2001-2010/2004/wp04_9.pdf>. p. 3; the seminal articulation of this theory is MARCH, James G.; OLSEN, Johan P. Rediscovering Institutions: The Organizational Basis of Politics. New York: Free Press, 1989.

${ }^{66}$ See, e.g. WHITTINGTON, Keith E. Once More Unto the Breach: PostBehavioralist Approaches to Judicial Politics. Law \& Social Inquiry, vol. 25, no. 2, p. 601-634, Apr. 200.

${ }^{67}$ HILBINK, Lisa. Judges Beyond Politics in Democracy and Dictatorship: Lessons from Chile, Cambridge Studies in Law and Society. Cambridge: Cambridge University Press, 2009; see, more generally HILBINK, Lisa. The Origins of Positive Judicial Independence. World Politics, vol. 64, no. 4, p. 567-621, 2012.

${ }^{68}$ The specific mechanisms at work in this process are myriad and, in general, not mutually exclusive. See, e.g. RAMSEYER, Mark J.; RASMUSEN, Eric B. Why Are Japanese Judges So Conservative in Politically Charged Cases? American Political Science Review, vol. 95, no. 2, p. 331-344, 2001; POSNER, Richard A. Judicial Behavior and Performance an Economic Approach. Florida State University Law Review, vol. 32, 2004/2005. p. 62; EPSTEIN,
} 
of law in society, these judicial-cultural norms will have a strong conditioning influence on how judges approach their work, including the interpretation of social rights.

\subsubsection{Brazilian Judicial Culture}

In Brazil, the culture of the judiciary has historically been both conservative and formalist. Through the 1970s judges aimed to be strict interpreters of "the law." At least in part, this was because of the protection from political interference offered by the approach. But it was also the product of a system of legal education and judicial selection that emphasized this approach as the correct way to fulfill the judicial function. The professoriate has traditionally been, ${ }^{69}$ and with notable exceptions continues to be, ${ }^{70}$ practicing lawyers for whom "[t]eaching is more like a hobby, with the main benefit being the prestige it offers."71 Consequently, there is little emphasis placed on original research and a substantial resistance to change, both conceptually and pedagogically. ${ }^{72}$

The judiciary is a professional one, selected-as most Brazilian public positions are-by public examination. For the ordinary courts, examinations are specific to the jurisdiction and are both set and administered by the judiciary itself. The contents of the examinations have traditionally focused heavily on substantive knowledge of the law in force as opposed theoretical or conceptual knowledge. This approach has been criticized as resulting in a particular, narrow range of successful candidates who are familiar with doctrine but lack professional and administrative experience. ${ }^{73}$ In the State of São Paulo, for example, Brinks notes that critics of the system of judicial selection

Lee; KNIGHT, Jack. Reconsidering Judicial Preferences. Annual Review of Political Science, vol. 16, no. 1, p. 11-31, 2013.

${ }^{69}$ HORACK, H. Claude. Legal Education in the Latin-American Republics. Journal of Legal Education, vol. 2, 1950. p. 288.

70 FRAGALE FILHO, Roberto. Brazilian Legal Education: Curricular Reform That Goes Further without Going Beyond. German Law Journal, vol. 10, 2009. p. 763.

${ }^{71}$ Junqueira, for example, has observed that "We began the 1970s trying to increase the number of law programs. We end[ed] the 1990s afraid of the uncontrolled proliferation of law schools and worried about the quality of law programs and future legal professionals. The on-site inspections of all law schools attest[ed] to the low quality of the programs, which have large classes, little infrastructure, and professors without credentials." JUNQUEIRA, Eliane Botelho. Brazil: The Road to Conflict Bound for Total Justice. In: FRIEDMAN, Lawrence M.; PÉREZ-PERDOMO, Rogelio (Ed.). Legal Culture in the Age of Globalization: Latin America and Latin Europe. Stanford: Stanford University Press, 2003 p. 89.

${ }^{72}$ Fregale Filho, for example, notes that:"... a curriculum modification does not necessarily change old teaching habits and little has been said (or done) about it. Pedagogical and curricular innovations are foreign to Brazilian law school classrooms... Most of all, as the majority of Brazilian law teachers also practice another legal profession, the classroom becomes an extension of their professional offices where they recite and reproduce their most up-to-date everyday judicial experience. This teaching style has been under scrutiny as the legitimacy of teachers has been called into question in the wake of the higher education expansion and the implementation of an evaluative public system." " FRAGALE FILHO, Roberto. Brazilian Legal Education: Curricular Reform That Goes Further without Going Beyond. German Law Journal, vol. 10, 2009. p. 762.

${ }^{73}$ PRILLAMAN, William C. The Judiciary and Democratic Decay in Latin America: Declining Confidence in the Rule of Law. Westport, Conn.: Praeger, 2000. p. 77. 
argue that the selection process privileges the memorization of existing doctrine at the expense of innovation, a preference that is seen to inhibit the development of socially conscious law. ${ }^{74}$

Nevertheless, by the mid-1980s, some judges began to confront the political establishment in the context of privatization. Although the STF generally overturned them, these decisions highlighted the relationship of law to social conditions and, to some degree, brought (and brings) into question the appropriateness of the strict legalist approach. ${ }^{75}$ By the early 1990 s, a generation of more progressively minded lawyers and judges had populated the junior ranks of the legal profession. Along with a smaller, more senior group of similarly disposed judges they sought to use their skill and position to aid the disadvantaged and foster progressive change in Brazil. ${ }^{76}$ It seemed clear that the generous social rights guarantees entrenched in the 1988 constitution could be used to further these goals. However, the means of doing so without transgressing the boundary between law and politics instilled in them by their education and Brazilian judicial culture was not.

This confluence of events was a critical juncture-a point in time when two or more relatively stable trajectories are more or less equally possible and the factor(s) that result in movement along one trajectory over the other(s) are exogenous, and often somewhat arbitrary. ${ }^{77}$ Applying the concept to the Brazilian experience, I argue that more or less by coincidence, willing ordinary court judges encountered a mobilized set of organizations seeking to advance HIV/AIDS awareness and treatment and a willing - or at least sufficiently fragmented as to be unable to mount effective opposition ${ }^{78}$ — set of domestic political institutions. ${ }^{79}$ These judges, then, were able to grant the individual

\footnotetext{
${ }^{74}$ BRINKS, Daniel M. Legal Tolls and the Rule of Law: The Judicial Response to Police Killings in South America. Paris: Notre Dame, 2004. p. 218; see also, HAMMERGREN, Linn A. Envisioning Reform: Improving Judicial Performance in Latin America. University Park: Pennsylvania State University Press, 2007. p. 104.

75 JUNQUEIRA, Eliane Botelho. Brazil: The Road to Conflict Bound for Total Justice. In: FRIEDMAN, Lawrence M.; PÉREZ-PERDOMO, Rogelio (Ed.). Legal Culture in the Age of Globalization: Latin America and Latin Europe. Stanford: Stanford University Press, 2003. p. 90.

${ }^{76}$ Although the motivation for doing so is surely complex, I do not think it unreasonable to suggest that, in varying proportions, both altruism and a desire for personal and institutional prestige played a substantial role.

${ }^{77}$ There are extensive literatures on this type of analysis in political science, economics, and elsewhere. Particularly strong articulations of the relevant ideas can be found in: THELEN, Kathleen. Historical Institutionalism in Comparative Politics. Annual Review of Political Science, vol. 2, p. 369-404, 1999; PIERSON, Paul. Increasing Returns, Path Dependence, and the Study of Politics. American Political Science Review, vol. 94, no. 2, p. 251-267, 2000; BAUMGARTNER, Frank R., et al. Punctuated Equilibrium in Comparative Perspective. American Journal of Political Science, vol. 53, no. 3, p. 603-620, 2009.
}

${ }^{78}$ FEREJOHN, John A. Judicializing Politics, Politicizing Law. Law and Contemporary Problems, vol. 61, p. 41$68,2002$.

${ }^{79}$ See, generally PIOVESAN, Flavia, Brazil: Impact and Challenges of Social Rights. in the Courts. In: LANGFORD, M. (ed.). Social Rights Jurisprudence: Emerging Trends in International and Comparative Law. Cambridge: Cambridge University Press, 2009; NOVOGRODSKY, Noah. Duty of Treatment Human Rights and the HIV/AIDS Pandemic. Yale Human Rights \& Development Law Journal, New Haven, vol. 12, 2009. p. 1.; HOFFMAN, Florian F.; BENTES, Fernando R. N. M. Accountability for Social and Economic Rights in Brazil. In: GAURI, Varun Gauri; 
claims for state provision of antiretrovirals in accordance with their positivist norms because, by conceiving of the rights as absolutes, they could be decided syllogstically without violating the separation of law and politics. This combination of a supportive judiciary and a willing, observant "support structure" proved an important force in Brazilian politics. Indeed, it is generally seen as the primary motivating force behind the passage of Law 9313 (approved in 1996), which provides antiretrovirals free of charge. ${ }^{80}$ More generally, Brazilian policy regarding HIV/AIDS is seen as highly successful, something that reflects well on the actions of the judiciary in this regard. ${ }^{81}$

Although the Brazilian legal tradition did not initially include substantive rights, the entrenchment of social rights in the 1988 Constitution coupled with the self-perception of the judicial community as a benevolent group of elites resulted in a desire and ability to use the law to aid those seeking the state-provision of antiretrovirals. In doing so, rather than challenging the fundamental assumptions about the nature of law as a separate, technical entity with objective answers, judges incorporated the right to health into the existing cannon, as an absolute principle. The initial success of the HIV/AIDS litigation strategy - that could succeed because it was a relatively clearly defined, limited policy with widespread support-established that approach as a viable means of achieving the twin goals of doing law and fostering progressive change. The acceptance of this norm effectively foreclosed engagement with socio-legal investigation of the effects of positive rights adjudication, domestically or internationally. Proportional or consequential reasoning were not in accordance with Brazilian legal culture; besides, the internal impetus for change had been satisfied.

\subsubsection{South African Judicial Culture}

The education, socialization, and professional norms of South African judges led them to approach social rights in a fundamentally different manner than their Brazilian counterparts. Three principal factors contributed to this difference and, in turn, to the divergent approach to social rights interpretation. The first was the relative amenability of the South African judges to the consideration of public policy and the process of

BRINKS, Daniel M.(ed.). Courting Social Justice: Judicial Enforcement of Social and Economic Rights in the Developing World. New York: Cambridge University Press, 2008. p. 126.

${ }^{80}$ NOVOGRODSKY, Noah. Duty of Treatment Human Rights and the HIV/AIDS Pandemic. Yale Human Rights \& Development Law Journal, New Haven, vol. 12, 2009. p. 28.

81 PIOVESAN, Flavia, Brazil: Impact and Challenges of Social Rights. in the Courts. In: LANGFORD, M. (ed.). Social Rights Jurisprudence: Emerging Trends in International and Comparative Law. Cambridge: Cambridge University Press, 2009. p. 190. It should, however, be noted that as early as 2001 there was concern that "Uninformed judges facing inadequate prescriptions couched in the rhetoric of a life and death emergency would ... all too easily fall prey to scientifically (and economically) unsound 'fashion prescriptions."'HOFFMAN, Florian F.; BENTES, Fernando R. N. M. Accountability for Social and Economic Rights in Brazil. In: GAURI, Varun Gauri; BRINKS, Daniel M.(ed.). Courting Social Justice: Judicial Enforcement of Social and Economic Rights in the Developing World. New York: Cambridge University Press, 2008. p. 132. 
balancing as compared to Brazilian judges. The South African courts did, like those in Brazil, exhibit a substantial degree of formalism during the authoritarian era. However, that formalism does not appear to have been as deeply ingrained in the judicial culture as it was in Brazil. Rather, it seems to have manifest in a subset of judges who, by virtue of judicial appointments being a discretionary power of the government of the day, were placed on the bench and assigned to the politically significant cases. As is the case in most jurisdictions, the bulk of the caseload was not politically sensitive. This meant that a relatively small number of sympathetic and/or compliant judges in the right positions could, and did, ensure that the majority of politically sensitive cases were heard by the "right people." 82 Nor was it as widely accepted in the broader legal community, as evidence by the variety and veracity of criticism of the apartheid legal order. ${ }^{83}$ More broadly, although common law reasoning and argumentation is quite adaptable to formalism, it is also capable-much more capable than at least the Brazilian variant of civil law reasoning, I would argue-of incorporating the type of public policy considerations and balancing of competing interests.

The second factor is the nature of legal education in South Africa. In South Afri$\mathrm{ca}$, the professoriate is substantially more likely to engage in teaching as a full-time occupation and, in turn, to engage in research. The products of this research were often quite critical of the apartheid regime and developed a variety of legally-grounded strategies and approaches for opposing it. ${ }^{84}$ In addition, in contrast to the relatively limited pool of judges and defense lawyers engaged in anti-establishment lawyering in Brazil, the anti-apartheid movement was something approaching mainstream in the public law side of the legal academy, as evident in the affiliation of a number of legal clinics and research centres associated with the anti-apartheid movement that were affiliated with university law schools. ${ }^{85}$

The third is the difference in the nature of judging as a professional activity. South African judges are selected from the ranks of senior legal practitioners, traditionally those who had been accorded the title of Senior Counsel. ${ }^{86}$ Invariably, the Bench was a

\footnotetext{
${ }^{82}$ HODES, Peter. Interview on 29 Apr. 2016

${ }^{83}$ E.g., MILLNER, M. A. Apartheid and the South African Courts. Current Legal Problems, vol. 14, n. 1, p. 280306, 1961; KENTRIDGE, Sydney. Telling the Truth About Law. South African Law Journal, vol. 99, no. 4, p. 648655, 1982; WACKS, Raymond. Judges and Injustice. South African Law Journal, vol. 101, 1984. p. 264.

${ }^{84}$ See e.g., CAMERON, Edwin. Legal Chauvinism, Executive-Mindedness and Justice--L.C. Steyn's Impact on South African Law. South African Law Journal, vol. 99, p. 38-75, 1982; DUGARD, John. Human Rights and the South African Legal Order. Princeton: Princeton University Press, 1978; FORSYTH, C. F. In Danger for Their Talents: A Study of the Appellate Division of the Supreme Court of South Africa from 1950-80. Cape Town: Juta, 1985; cf. A BLERK, Adrienne E. Van. Judge and Be Judged. Cape Town: Juta, 1988.

${ }^{85}$ For example, the Centre for Applied Legal Studies, founded by John Dugard and affiliated with the University of the Witwatersrand.

${ }^{86}$ The term is analogous to United Kingdom's "Queen's Counsel," a title bestowed on barristers who have distinguished themselves in the profession through long service.
} 
second career for those with both practice and life experience. This is a marked contrast to Brazilian judges of first instance, who tended to be young, steeped in formal reasoning, and have relatively limited experience outside of the formal study of law.

In combination, these factors produced a system of legal education, socialization, and professional norms that predisposed the judiciary to approach the issues raised by social rights adjudication in a more pragmatic, policy-oriented fashion concerned with maintaining a balance between the proper role of the courts and the necessity of giving effect to the transformative guarantees present in the Constitution.

\subsection{Institutional Design}

Three aspects of institutional design also contributed to the initial and continued divergence of the social rights jurisprudence of South Africa and Brazil. The first of these has to do with the actual number of judges in each jurisdiction, the second with doctrine of precedent, and the third with the nature of the apex courts.

In 2013, there were 239 permanent judges of the South African high courts; in Brazil there were a combined total of 12,810 judges in the federal and state courts. ${ }^{87}$ This works out to roughly 0.45 judges per hundred thousand people in South Africa and 6.33 per hundred thousand in Brazil. ${ }^{88}$ Thus, the number of judges capable of engaging in judicial review on constitutional grounds in each jurisdiction is radically different. In terms of workload, however, Brazilians are notoriously litigious. In the same year, 21.5 million new cases - just shy of 1,700 per judge-were filed with those courts and there were substantially more than that already in the systems. ${ }^{89}$ While I have not been able to obtain comprehensive data on caseload or new filings for South Africa, court-specific comparisons suggest a significant difference in workload and, by extension, approach to adjudication. For example, the Constitutional Court of South Africa and the Supremo Tribunal Federal are both, in theory, the apex court for constitutional matters only. The South African Court deals with 40-50 cases per year, the STF deals with roughly 70,000. Quite simply, Brazilian judges lack the time to engage in the type of sustained research and analysis necessary to engage in policy-cognizant balancing and analysis.

The second institutional factor is the doctrine of stare decisis. In South Africa, hierarchical precedent is an accepted fact of the courts. When a court issues a clear decision on how the law is to be interpreted, that interpretation is almost invariably applied by courts lower in the judicial hierarchy. The matter, then, is settled. With

\footnotetext{
${ }^{87}$ LAW SOCIETY OF SOUTH AFRICA. Statistics for Legal Education and Development (LEAD) and the Legal Profession, 2013-2014, June 2014; CONSELHO NACIONAL DE JUSTIÇA. Justiça Em Números 2014 Brasília: Departamento de Pesquisas Judiciárias, 2014.

${ }^{88}$ Authors calculations based on World Bank population data for 2013.

${ }^{89}$ CONSELHO NACIONAL DE JUSTIÇA. Justiça Em Números 2014 Brasília: Departamento de Pesquisas Judiciárias, 2014.
} 
certain exceptions, ${ }^{90}$ Brazil has no formal system of binding precedent and the vast majority of decisions apply only to the dispute before the judge. Despite the fact that Brazilian judicial review exhibits a strong Anglo-American influence, the legal system and its procedure remain firmly grounded in the civil law tradition. And, in this respect, there is generally not a clear line of reasoning and decisions in the sense thought of by Anglo-American legal scholars. This is the case for at least two reasons. The first is the lack of a functional system of case citation that would enable various decisions to be tracked in order to determine if their reasoning and decisions had been upheld, ignored, or outright rejected. This is particularly problematic in a jurisdiction with dozens of autonomous or semi-autonomous judicial organs handling tens of millions of cases per year. ${ }^{91}$ The second is the vigorously defended individual autonomy of individual judges at all levels to decide cases according to "the law" as opposed to directives from other judges. ${ }^{92}$

Finally, the marked differences in the composition and operation of the two apex constitutional courts has also contributed to the divergence in social rights interpretation. Although the 1988 Constitution is a transformative Constitution that included numerous social guarantees and mechanisms for their defense, the judiciary tasked with interpreting and applying it was not new. The judges initially tasked with its interpretation were the same ones who had been appointed and presided over the courts during the dictatorship. This included the apex court for all constitutional matters - the STF — which had vehemently lobbied against its replacement by a newly constituted constitutional court. Instead, the STJ was created as an attempt to reduce the non-constitutional caseload of the STF. An endeavor into constitutional engineering that has had only limited success, as evident in the STF's caseload, discussed above. ${ }^{93}$ This meant that of the eleven judges on the court when the 1988 constitution came into effect, the unexpected president, Jose Sarney had appointed two and the remaining nine had been appointed by three different presidents during the military regime. ${ }^{94}$

\footnotetext{
${ }^{90}$ Abstract review, the sole prerogative of the STF is, by definition, generally applicable. Additionally, Constitutional Amendment No. 45 of 2004 gave the STF the ability to create a weak form of vertical precedent-the Súmula Vinculante-when certain conditions were met.

${ }^{91}$ FALCÃO, Joaquim. Interview on 10 November 2014.

${ }_{92}$ OLIVEIRA, Maria Angela Jardim de Santa Cruz. Reforming the Brazilian Supreme Federal Court: A Comparative Approach. Washington University Global Studies Law Review, vol. 5, p. 139-142, 2006.

${ }^{93}$ Although the modern STJ was intended to function as the apex court for non-constitutional matters, leaving the STF free to deal with constitutional issues, in practice a broad definition of what constitutes a constitutional matter, a variety of institutional factors incentivizing successive appeals, and the limited impact of previous decisions have frustrated that intention.

${ }^{94}$ The eleven members of the Court at that time were Ministers Aldir Passarinho, Carlos Madeira, Célio Borja, Djaci Falcão, Francisco Rezek, Moreira Alves, Néri da Silveira, Octavio Gallotti, Oscar Corrêa, Rafael Mayer (President), and Sydney Sanches.
} 
The South African Constitutional Court was a newly created body tasked solely with the adjudication of constitutional matters, given a strong mandate to defend the constitution, and accorded a great deal of leeway-including control over its docketin how to do so. Perhaps most importantly, however, the Court was composed largely of progressive-minded judges and academics in contrast to the initial composition of Brazil apex constitutional court. The first South African Court was headed by Arthur Chaskalson, co-founder of the Legal Resources Center and included Ismael Mahomed, the first non-White judge in South Africa, as well as Albie Sachs, an advocate whose defence of those imprisoned under various racial and security statutes lead to his own imprisonment, exile, and eventual maiming. By populating the court with a combination of experienced judges, legal activists, and academics, the court had the capacity to draw on a multitude of perspectives as well as a predilection to advance the goals of the new constitution.

The decision-making procedure of the two courts is also radically different. The South African Court, with control over its docket tends to focus on a relatively limited number of cases per year, sitting almost exclusive as a full bench when considering the substance of any matter. Each judge, assisted by their clerks, is responsible for reviewing the submissions of the parties and conducting any additional research they feel necessary before oral arguments. Oral arguments are then followed by an in camera conference and the eventual assignment of opinion writing responsibilities. At the STF, the bulk of the decisions are actually handled by a single judge in Chambers (monocratic decisions). Nonetheless, something like 2,000 cases per year are decided by one of three collegiate bodies: the two sub-panels (turmas) of five Ministers (the President of the Court is not a member of either turma) and the plenary court. When a case formally enters the Court's docket, one of the Ministers (with the exception of the President of the Court) is randomly assigned as that case's reporter (relator). The reporter is responsible for moving the case through the Court's bureaucracy and, if the case is judged by a collegiate body, the reporter must come to the collegiate session with (i) a summary of the facts, which is distributed beforehand to all Justices, and (ii) their written opinion-which is only announced to the rest of the Court during the public session. All deliberation between Ministers is therefore public and at least formally, there is no prior or private discussion of pending cases among the judges..$^{95}$ After the

\footnotetext{
${ }^{95}$ In interviews conducted by Fernando Fontainha as a part of the Supreme Court Oral History Project (História Oral do Supremo (1988-2013)), some Ministers do mention episodes in which they met prior to hearingssometimes in an administrative (i.e., non-judicial, non-deliberative) session in the Court's building, sometimes in their own homes - to discuss important cases or crucial political events that might affect the Court and its decisions. See, for example, the interviews of Justices Carlos Velloso (unpublished interview, on file with the author), Rafael Mayer (unpublished interview, on file with the author) and Nelson Jobim (unpublished interview, on file with the author). Other Ministers vehemently deny that such meetings occur, and even the Ministers mentioned above do not describe these meetings as regular.
} 
reporter has issued his opinion, the rest of Ministers issue their own opinions and vote, in reverse order of seniority. These subsequent opinions may be as simple as indicating agreement with the reporter or extremely detailed treatises on the subject. Although Ministers can explicitly state that they are following the opinion of this or that colleague, there is no formal aggregation of individual opinions into a collective majority opinion. ${ }^{96}$

\subsection{Summary}

In short countries with a highly decentralized system of judicial review, characterized by a large number of judges who are relatively inexperienced, steeped in formalism, and who are have little or no obligation to abide by previously decided cases will tend to develop an individualized social rights jurisprudence that focuses on remedying specific harms. Those with a more centralized system of judicial review, characterized by a small number of experienced judges more experienced in a consequentialist type of reasoning and operating in a system which has a strong adherence to stare decisis, will develop a more policy-oriented social rights jurisprudence that emphasizes the importance of addressing structural problems.

\section{IMPLICATIONS}

The individualized approach of the Brazilian judiciary, particularly in the area of right to health litigation, has attracted a great deal of attention. Initial analyses of social rights litigation in Brazil advanced a positive view of the judicialization of healthcare. Passarelli and Terto Júnior, for example, concluded that a key driver of Brazil's success in the treatment of HIV/AIDS was the use of the litigation to give force and effect to the principles underlying the unified health system. ${ }^{97}$ Writing in 2008, Piovesan noted an emerging trend of right to health litigation that included "judicial rulings on the free provision of medicine, which, coupled with well-coordinated and efficient litigation strategies, have prompted changes in the law and the adoption of public policies that are considered exemplary." 98

In addition to these more transformative decisions, litigation has also been seen as an effective means of ensuring accountability within the complex system of

\footnotetext{
${ }^{96}$ For a critical analysis of the STF's decision-making practices, see SILVA, Virgílio Afonso da. Deciding without Deliberating. International Journal of Constitutional Law, vol. 11, no. 3, p. 557-584, 2013.

97 PASSARELLI; TERTO JÚNIOR. Non-Governmental Organizations and Access to Anti-Retroviral Treatments in Brazil. Divulgação em Saúde para Debate, Rio de Janeiro, n. 27, p. 252-264, Aug. 2003. p. 256; FLYNN, Matthew. Public Production of Anti-Retroviral Medicines in Brazil, 1990-2007. Development and Change, vol. 39, no. 4, 2008. p. 520.

${ }_{98}$ PIOVESAN, Flavia, Brazil: Impact and Challenges of Social Rights. in the Courts. In: LANGFORD, M. (ed.). Social Rights Jurisprudence: Emerging Trends in International and Comparative Law. Cambridge: Cambridge University Press, 2009. p. 189.
} 
government organizations that make up Brazil's public health system..$^{99}$ In a study of right to health litigation in Rio de Janeiro, for example, Borges and Ugá found that more than half (52\%) of the medication being sought was officially supplied. This was taken to suggest inefficiency in the administration and/or delivery of required services. ${ }^{100}$ Others, however, have suggested that this is a least partly the result of litigants including multiple medications-both covered and not-in their claims and claimants seeking medication for "off-label" (prescribed for condition other than one the drug was approved for) or off protocol (the patient does not meet the clinical criteria established for prescription) use. ${ }^{101}$ It should also be remembered that this form of litigation is at least as much administrative as it is constitutional.

Nevertheless, as early as 2007 concerns were being raised about judicial involvement in the distribution of medicines. Vieira and Zucchi, for example, argued that "to take as a starting point the assumption that any claim for medication should be met, since the right to health is guaranteed, reveals... a lack of understanding of public health policies and the accompanying pharmaceutical management."102 A number of empirical studies support this claim insofar as they identify substantial costs incurred by state actors in complying with judicial mandates of this type as well as exponential rises in pharmaceutical expenditures, and health expenditures more generally, that are correlated with increases in right to health litigation. ${ }^{103}$

Subsequently, Ferraz identified equity concerns with this "Brazilian model" of individualized right to health litigation for publicly-funded curative treatment in which litigants have an extremely high success rate. This model of adjudication, he argued,

\footnotetext{
${ }_{99}$ Biehl et al., for example, found that "Many judges and public defenders working on right-to-health cases feel they are responding to state failures to provide needed drugs." BIEHL, et al. Judicialisation of the Right to Health in Brazil. The Lancet, vol. 373, no. 9682, June 2009. p. 2183.

100 BORGES, Danielle; UGÁ, Maria Alicia Dominguez. Conflitos e Impasses Da Judicialização Na Obtenção de Medicamentos: As Decisões de 1a Instância Nas Ações Individuais Contra o Estado Do Rio de Janeiro, Brasil, Em 2005. Cadernos de Saúde Pública, v. 26, no. 1, p. 60-62, jan. 2010. p. 62-67.

101 WANG, Daniel W. Liang; FERRAZ, Octavio Luiz Motta. Reaching Out to the Needy? Access to Justice and Public Attorneys' Role in Right to Health Litigation in the City of São Paulo. SUR - International Journal on Human Rights, vol. 10, no. 18, June 2013. p. 9.

102 VIEIRA, Fabiola Sulpino; ZUCCHI, Paola. Distortions to National Drug Policy Caused by Lawsuits in Brazil. Revista de Saúde Pública, vol. 41, no. 2, 2007. p. 8.

${ }^{103}$ VIEIRA, Fabiola Sulpino; ZUCCHI, Paola. Distortions to National Drug Policy Caused by Lawsuits in Brazil. Revista de Saúde Pública, vol. 41, no. 2, 2007; CHIEFFI, Ana Luiza; BARATA, Rita de Cássia Barradas. Ações Judiciais: Estratégia Da Indústria Farmacêutica Para Introdução de Novos Medicamentos. Revista de Saúde Pública, vol. 44, no. 3, p. 421-429, 2010;

PEREIRA, Januária Ramos et al. Análise Das Demandas Judiciais Para o Fornecimento de Medicamentos Pela Secretaria de Estado Da Saúde de Santa Catarina Nos Anos de 2003 e 2004. Ciência \& Saúde Coletiva, vol. 15, no. 3, p. 3551-3560, Nov. 2010; LOPES, Luciane Cruz et al. Rational Use of Anticancer Drugs and Patient Lawsuits in the State of São Paulo, Southeastern Brazil. Revista de Saúde Pública, vol. 44, no. 4, p. 620-628, Aug. 2010; MEDEIROS, Marcelo; DINIZ, Debora; SCHWARTZ, Ida Vanessa Doederlein. A Tese da Judicialização da Saúde Pelas Elites: Os Medicamentos Para Mucopolissacaridose. Ciência \& Saúde Coletiva, vol. 18, no. 4, p. 1079-1088, 2013.
} 
both impaired efficient allocation of resources and privileged those who are able to access the courts, an ability generally associated with socio-economic advantage. Although partly supported by subsequent research, ${ }^{104}$ the difficulties associated with reliably tracking right to health litigation noted above in conjunction with those relating to the identification of litigants' socio-economic status have thus far impeded authoritative empirical analysis of this theory.

At the same time, several scholars have argued that these decisions have had positive indirect effects on access to social benefits. The prime example of this is Brazil's policy of universal antiretroviral provision. The move toward a national policy of universal provision is attributable to a number of actors, including the sanitaristas and various advocacy groups, however, there is a general agreement that the courts also played an important role in the creation of this policy in both São Paulo and Rio Grande do Sul and then at the federal level. ${ }^{105}$ The 2012 creation of a federal institution to deal with the assessment of healthcare technology (the Comissão Nacional de Incorporação de Tecnologias or CONITEC), including pharmaceuticals, is likely a second such instance. ${ }^{106}$, CONITEC has been criticised for a "[l]ack of objective clinical evaluation criteria... on what is more efficacious or safe [and the] absence of clear parameters for the analysis of cost effectiveness," ${ }^{\prime 107}$ as well as having a mandate that emphasizes new, high-cost medicines. ${ }^{108}$

This is not to say that the "reasonableness" approach is without it's criticisms as well. At least with respect to HIV, it may well be that the South African Constitutional Court's single, clear, and precedential decision regarding the necessity of a reasonable policy regarding the distribution of antiretrovirals, particularly with respect to the prevention of mother-to-child transmission, was expediently and effectively implemented. By 2010 (the first year for which reliable comparative data is available) 93\% of pregnant

\footnotetext{
${ }^{104}$ SILVA, Virgilio Afonso da; TERRAZAS, Fernanda Vargas. Claiming the Right to Health in Brazilian Courts: The Exclusion of the Already Excluded? Law \& Social Inquiry, vol. 36, no. 4, p. 825-853, 2011; BRINKS, Daniel M; GAURI, Varun. Law's Majestic Equality? The Distributive Impact of Litigating Social and Economic Rights. Policy Research Working Paper, The World Bank Development Research Group, Mar. 2012. p. 383; WANG, Daniel W. Liang; FERRAZ, Octavio Luiz Motta. Reaching Out to the Needy? Access to Justice and Public Attorneys' Role in Right to Health Litigation in the City of São Paulo. SUR - International Journal on Human Rights, vol. 10, no. 18, June 2013.

${ }^{105}$ E.g., PASSARELLI; TERTO JÚNIOR. Non-Governmental Organizations and Access to Anti-Retroviral Treatments in Brazil. Divulgação em Saúde para Debate, Rio de Janeiro, n. 27, p. 252-264, Aug. 2003. p. 257.

106 WANG, Daniel. Courts as Healthcare Policy-Makers: The Problem, the Responses to the Problem and Problems in the Responses. Direito FGV Research Paper Series, São Paulo, Paper n. 75. p. 44; BORGES, Danielle da Costa Leite. Individual Inputs and Collective Outputs: Understanding the Structural Effects of Individual Litigation on Healthcare in Brazil. FGV Direito Rio - Working Paper, 2014. p. 12-13..

${ }^{107}$ RODRIGUES, Tania; IZMIRLIEVA, Milena; ANDO, Gustavo. Analysis of Brazilian Public Funding Process for New Biologic Drugs. Value in Health, vol. 16, no. 7, 2013. p. A678.

108 OSORIO-DE-CASTRO, Claudia G. S., et al. Policy Change and the National Essential Medicines List Development Process in Brazil Between 2000 and 2014: Has the Essential Medicine Concept Been Abandoned? Basic \& Clinical Pharmacology \& Toxicology, 2017. Available at: <https://doi.org/10.1111/bcpt.12932>.
} 
women with HIV were receiving antiretroviral therapy for the prevention of mother-tochild transmission, a number which has remained relatively constant since. In Brazil, the rate of coverage in 2010 was $56 \%$, although is increased to $89 \%$ by $2016 .{ }^{109}$ However, the general rates of antiretroviral therapy coverage show a markedly different pattern. By 2000 (also the first year for which data is available), 27\% of Brazilians with HIV were receiving antiretroviral therapy in contrast to a reported $0 \%$ in South Africa. It took until 2011 for South Africa to reach the level of coverage in Brasil in 2000, by which time the Brazilian coverage was $40 \%$. As of 2016 , coverage is $60 \%$ and $56 \%$, respectively. More troublingly, however, is the massive variation in HIV prevalence. In 1990, 0.2\% of Brazilians 15-49 were living with HIV as were $0.7 \%$ of South Africans. By 2000 , it was $0.3 \%$ and $12.0 \%$ and by $2010,0.5 \%$ and $18.2 \%$. The South African Constitutional Court decision may have effected a significant structural change, but the sustained individualized litigation of the Brazilian context appears, at least on its face, to have proven more successful in addressing the broader public health issue.

\section{CONCLUSION}

Social rights guarantees are now a feature of the majority of the world's constitutions. They have been variously characterized as tools for the realization of progressive social transformation and window dressings aimed at diverting attention from ongoing human rights abuses, democracy enhancing and anti-majoritarian, good and bad. At present, however, we are still in the early stages of understanding the long term social, economic, and political effects of their constitutionalization and subsequent litigation and judicial interpretation. As we seek to develop our knowledge in this area, we should bear a number of things in mine. First, the institutional environment in which a constitution is interpreted and applied matters: professional cultures shape both what judges seek to achieve and how they are able to pursue those ends; formal institutional design determines the kinds of decisions they are able to make and, in turn, will shape whether and how interest groups, civil society actors, and individuals will seek judicial assistance in achieving their goals. Second, variations in institutional design and standard practices mean that one cannot assume that a focus on apex court decisions will provide an accurate understanding of a given country's interpretation and application of social rights. Finally, like most broad political phenomena, the trend toward the constitutionalization of social rights ought not be viewed as an inherent good, nor should the effects be expected to be uniform. It is better conceived of as a malleable process, subject to a variety of influences, the implementation and operation of which are sure to have consequences, intended and otherwise.

\footnotetext{
${ }^{109}$ Data in this section is based on UNAIDS estimates and was retrieved from the World Bank's World Development Indicators Database (https://data.worldbank.org/products/wdi) in February 2018.
} 


\section{REFERENCES}

ARGUELHES, Diego Werneck; HARTMANN, Ivar. A. Law in the Books and Books in the Court. Are Social Rights Literature and Judicial Practice on the same page in Brazil? Annuaire International des Droits de L'Homme. v. VII. Athens: Sakkoulas, 2014.

BADAT, Saleem; SAYED, Yusuf. Post-1994 South African Education: The Challenge of Social Justice. The ANNALS of the American Academy of Political and Social Science, vol. 652, no. 1, p. 127148, 2014.

BAUMGARTNER, Frank R., et al. Punctuated Equilibrium in Comparative Perspective. American Journal of Political Science, vol. 53, no. 3, p. 603-620, 2009.

BIEHL, et al. Judicialisation of the Right to Health in Brazil. The Lancet, vol. 373, no. 9682, June 2009.

BILCHITZ, David. Towards a Reasonable Approach to the Minimum Core: Laying the Foundations for Future Socio-Economic Rights Jurisprudence. South African Journal on Human Rights, vol. 19, 2003.

BLERK, Adrienne E. Van. Judge and Be Judged. Cape Town: Juta, 1988.

BORGES, Danielle da Costa Leite. Individual Inputs and Collective Outputs: Understanding the Structural Effects of Individual Litigation on Healthcare in Brazil. FGV Direito Rio - Working Paper, 2014.

BORGES, Danielle; UGÁ, Maria Alicia Dominguez. Conflitos e impasses da judicialização na obtenção de medicamentos: as decisões de 1 a instância nas ações individuais contra o Estado do Rio de Janeiro, Brasil, em 2005. Cadernos de Saúde Pública, v. 26, no. 1, p. 60-62, jan. 2010.

BREWER-CARÍAS, Allan R. Constitutional Protection of Human Rights. In: Latin America: A Comparative Study of the Amparo Proceeding. New York: Cambridge University Press, 2008, p. 142-147.

BRINKS, Daniel M; GAURI, Varun. Law's Majestic Equality? The Distributive Impact of Litigating Social and Economic Rights. Policy Research Working Paper, The World Bank Development Research Group, Mar. 2012.

BRINKS, Daniel M. Legal Tolls and the Rule of Law: The Judicial Response to Police Killings in South America. Paris: Notre Dame, 2004.

BRINKS, Daniel M.; FORBATH, William. The Role of Courts and Constitutions in the New Politics of Welfare in Latin America. In: PEEREBOOM, Randall; GINSBURG, Tom (ed.). Law and Development of Middle-Income Countries: Avoiding the Middle-Income Trap. New York: Cambridge University Press, 2014.

CAMERON, Edwin. Legal Chauvinism, Executive-Mindedness and Justice--L.C. Steyn's Impact on South African Law. South African Law Journal, vol. 99, p. 38-75, 1982. 
CHIEFFI, Ana Luiza; BARATA, Rita de Cássia Barradas. Ações Judiciais: Estratégia Da Indústria Farmacêutica Para Introdução de Novos Medicamentos. Revista de Saúde Pública, vol. 44, no. 3, p. 421-429, 2010.

CONSELHO NACIONAL DE JUSTIÇA. Justiça Em Números 2014 Brasília: Departamento de Pesquisas Judiciárias, 2014.

COUTINHO, Maria Laura. Do Brazilian Courts Contribute to the Implementation of the Right to Housing? Fundação Getulio Vargas - Research Paper Series, São Paulo, Feb. 2014.

DANZIGER, Shai; LEVAV, Jonathan; AVNAIM-PESSO, Liora. Extraneous Factors in Judicial Decisions. Proceedings of the National Academy of Sciences, vol. 108, no. 17, Apr. 2011.

DONOHUE, Dana; BORNMAN, Juan. The Challenges of Realising Inclusive Education in South Africa. South African Journal of Education, vol. 34, no. 2, p. 01-14, June 2014.

DUGARD, John. Human Rights and the South African Legal Order. Princeton: Princeton University Press, 1978.

EPSTEIN, Lee; KNIGHT, Jack. Reconsidering Judicial Preferences. Annual Review of Political Science, vol. 16, no. 1, p. 11-31, 2013.

FEREJOHN, John A. Judicializing Politics, Politicizing Law. Law and Contemporary Problems, vol. 61, p. 41-68, 2002.

FERRAZ, Octavio Luiz Motta. Brazil: Are Collective Suits Harder to Enforce? In: LANGFORD, Malcolm; RODRIGUEZ-GARAVITO, Cesar; ROSSI; Julieta (ed.). Social Rights Judgments and the Politics of Compliance. Cambridge: Cambridge University Press, 2017.

FERRAZ, Octavio Luiz Motta. Right to Health Litigation in Brazil, An Overview of the Research. Right to Health Through Litigation? Can Court Enforced Health Rights Improve Health Policy? Workshop, University Torquato di Tella, Buenos Aires, 2009.

FERRAZ, Octavio Luiz Motta. The Right to Health in the Courts of Brazil: Worsening Health Inequities? Health and Human Rights, vol. 11, no. 2, p. 33-45, dec. 2009.

FLYNN, Matthew. Public Production of Anti-Retroviral Medicines in Brazil, 1990-2007. Development and Change, vol. 39, no. 4, 2008.

FORSYTH, C. F. In Danger for Their Talents: A Study of the Appellate Division of the Supreme Court of South Africa from 1950-80. Cape Town: Juta, 1985.

FRAGALE FILHO, Roberto. Brazilian Legal Education: Curricular Reform That Goes Further without Going Beyond. German Law Journal, vol. 10, 2009.

GREY, Thomas C. Langdell's Orthodoxy. University of Pittsburgh Law Review, vol. 45, 1983.

HAMMERGREN, Linn A. Envisioning Reform: Improving Judicial Performance in Latin America. University Park: Pennsylvania State University Press, 2007. 
HILBINK, Lisa. The Origins of Positive Judicial Independence. World Politics, vol. 64, no. 4, p. 567$621,2012$.

HILBINK, Lisa. Judges Beyond Politics in Democracy and Dictatorship: Lessons from Chile, Cambridge Studies in Law and Society. Cambridge: Cambridge University Press, 2009.

HOFFMAN, Florian F.; BENTES, Fernando R. N. M. Accountability for Social and Economic Rights in Brazil. In: GAURI, Varun Gauri; BRINKS, Daniel M.(ed.). Courting Social Justice: Judicial Enforcement of Social and Economic Rights in the Developing World. New York: Cambridge University Press, 2008. p. 119-27.

HORACK, H. Claude. Legal Education in the Latin-American Republics. Journal of Legal Education, vol. 2, 1950.

JUNG, Courtney; HIRSCHL, Ran; ROSEVEAR, Evan. Economic and Social Rights in National Constitutions. American Journal of Comparative Law, vol. 62, no. 4, p. 1043-1093, out. 2014.

JUNG, Courtney; HIRSCHL, Ran; ROSEVEAR, Evan. Justiciable and Aspirational ESRs in National Constitutions. In: YOUNG, Katherine G. (ed.) The Future of Economic and Social Rights. Cambridge: Cambridge University Press, 2018 (forthcoming).

JUNQUEIRA, Eliane Botelho. Brazil: The Road to Conflict Bound for Total Justice. In: FRIEDMAN, Lawrence M.; PÉREZ-PERDOMO, Rogelio (Ed.). Legal Culture in the Age of Globalization: Latin America and Latin Europe. Stanford: Stanford University Press, 2003.

KENTRIDGE, Sydney. Telling the Truth About Law. South African Law Journal, vol. 99, no. 4, p. 648-655, 1982.

LAW SOCIETY OF SOUTH AFRICA. Statistics for Legal Education and Development (LEAD) and the Legal Profession, 2013-2014, June 2014.

LIEBENBERG, Sandra. South Africa: Adjudicating Social Rights Under a Transformative Constitution. In: LANGFORD, Malcolm (ed.) Social Rights Jurisprudence: Emerging Trends in International and Comparative Law. New York: Cambridge University Press, 2008.

LOPES, Luciane Cruz et al. Rational Use of Anticancer Drugs and Patient Lawsuits in the State of São Paulo, Southeastern Brazil. Revista de Saúde Pública, vol. 44, no. 4, p. 620-628, Aug. 2010.

MARCH, James G.; OLSEN, Johan P. The Logic of Appropriateness. Arena - Centre for European Studies Working Papers, Paper n. 04/09, 2004. Available at: <https://www.sv.uio.no/arena/english/research/publications/arena-working-papers/2001-2010/2004/wp04_9.pdf>.

MARCH, James G.; OLSEN, Johan P. Rediscovering Institutions: The Organizational Basis of Politics. New York: Free Press, 1989.

MARCHANT, Anyda. The Brazilian Writ of Security (Mandado de Segurança) and Its Relationship to the Extraordinary Remedies of the Anglo-American Common Law: An Object Lesson in Latin American Law Making. Tulane Law Review, New Orleans, vol. 19, n. 214 p. 1944-1945. 
MARQUES, Silvia Badim; DALLARI, Sueli Gandolfi. Garantia Do Direito Social à Assistência Farmacêutica No Estado de São Paulo. Revista de Saúde Pública, vol. 41, n.1, p.101-107, 2007.

MARTIN, Charles E.; GEORGE, William Henry (eds). Consitution of Germany, 1919. In: Representative Modern Constitutions. MUNRO, William B.; HOLCOMBE, Arthur N. (Trad.) Los Angeles: Times-Mirror Press, 1923.

MCCONNACHIE, Cameron; MCCONNACHIE, Chris. Concretising the Right to a Basic Education. South African Law Journal, vol. 129, 2012.

MEDEIROS, Marcelo; DINIZ, Debora; SCHWARTZ, Ida Vanessa Doederlein. A Tese da Judicialização da Saúde Pelas Elites: Os Medicamentos Para Mucopolissacaridose. Ciência \& Saúde Coletiva, vol. 18, no. 4, p. 1079-1088, 2013.

MENICUCCI, Telma Maria Gonçalves; MACHADO, José Angelo. Judicialization of Health Policy in the Definition of Access to Public Goods: Individual Rights versus Collective Rights. trans. Leandro Moura. Brazilian Political Science Review, v. 4, no. 1, p. 48-49, jul. 2011.

MÉSZÁROS, George. Social Movements, Law, and the Politics of Land Reform: Lessons from Brazil, Law, Development and Globalization. Abingdon: Routledge, 2013.

MILLNER, M. A. Apartheid and the South African Courts. Current Legal Problems, vol. 14, n. 1, p. 280-306, 1961.

MNCUBE, Vusi S.; MADIKIZELA-MADIYA, Nomanesi. South Africa: Educational Reform - Curriculum, Governance and Teacher Education. In: HARBER, Clive (Ed.). Education in Southern Africa. London: Bloomsbury Academic, 2013.

NISIHARA, Renato Mitsunori; POSSEBOM, Ana Carolina; BORGES, Luiza de Martino Cruvinel; SHWERTZ, Ana Claudia Athanasio; BETTES, Fernanda Francis Benevides. Judicial Demand of Medications Through the Federal Justice of the State of Paraná [Demanda Judicial de Medicamentos Na Justiça Federal Do Estado Do Paraná], Einstein, Sao Paulo, v. 15, n. 1, p. 85-91, mar. 2017.

NOVOGRODSKY, Noah. Duty of Treatment Human Rights and the HIV/AIDS Pandemic. Yale Human Rights \& Development Law Journal, New Haven, vol. 12, 2009.

NUNN, Amy; DICKMAN, Samuel; NATTRASS, Nicoli; CORNWALL, Alexandra b; GRUSKIN, Sofia. The Impacts of AIDS Movements on the Policy Responses to HIV/AIDS in Brazil and South Africa: A Comparative Analysis. Global Public Health, vol. 7, n. 10, p. 1034-1038, nov. 2012.

OLIVEIRA, Maria Angela Jardim de Santa Cruz. Reforming the Brazilian Supreme Federal Court: A Comparative Approach. Washington University Global Studies Law Review, vol. 5, p. 139-142, 2006.

OLIVEIRA, Vanessa Elias; HOLDS, Lincoln Noronha. Judiciary-Executive Relations in Policy Making: The Case of Drug Distribution in the State of São Paulo. Brazilian Political Science Review, São Paulo, v. 5, n. 2, p. 10-38, jul. 2012. 
OSORIO-DE-CASTRO, Claudia G. S., et al. Policy Change and the National Essential Medicines List Development Process in Brazil Between 2000 and 2014: Has the Essential Medicine Concept Been Abandoned? Basic \& Clinical Pharmacology \& Toxicology, 2017. Available at: <https://doi. org/10.1111/bcpt.12932>.

PASSARELLI; TERTO JÚNIOR. Non-Governmental Organizations and Access to Anti-Retroviral Treatments in Brazil. Divulgação em Saúde para Debate, Rio de Janeiro, n. 27, p. 252-264, Aug. 2003.

PEASLEE, Amos J. (ed.) Constitution of the Argentine Republic, 1949. In: Constitutions of Nations Concord. NH: Rumford, 1950.

PEREIRA, Januária Ramos et al. Análise Das Demandas Judiciais Para o Fornecimento de Medicamentos Pela Secretaria de Estado Da Saúde de Santa Catarina Nos Anos de 2003 e 2004. Ciência \& Saúde Coletiva, vol. 15, no. 3, p. 3551-3560, Nov. 2010.

PEREIRA, José Gilberto; PEPE, Vera Lúcia Edais. Acesso a Medicamentos Por via Judicial No Paraná: Aplicação de Um Modelo Metodológico Para Análise e Monitoramento Das Demandas Judiciais. Revista de Direito Sanitario, v. 15, n. 2, p. 30-45. 2014.

PIERSON, Paul. Increasing Returns, Path Dependence, and the Study of Politics. American Political Science Review, vol. 94, no. 2, p. 251-267, 2000.

PIOVESAN, Flavia, Brazil: Impact and Challenges of Social Rights. in the Courts. In: LANGFORD, M. (ed.). Social Rights Jurisprudence: Emerging Trends in International and Comparative Law. Cambridge: Cambridge University Press, 2009.

POSNER, Richard A. Judicial Behavior and Performance an Economic Approach. Florida State University Law Review, vol. 32, 2004/2005.

PRADO, Mariana Mota. The Debatable Role of Courts in Brazil's Health Care System: Does Litigation Harm or Help? Journal of Law, Medicine \& Ethics, v. 41, n. 1, p. 124-137. 2013.

PRILLAMAN, William C. The Judiciary and Democratic Decay in Latin America: Declining Confidence in the Rule of Law. Westport, Conn.: Praeger, 2000.

RAMSEYER, Mark J.; RASMUSEN, Eric B. Why Are Japanese Judges So Conservative in Politically Charged Cases? American Political Science Review, vol. 95, no. 2, p. 331-344, 2001.

RICH, Jessica A. J. Grassroots Bureaucracy: Intergovernmental Relations and Popular Mobilization in Brazil's AIDS Policy Sector. Latin American Politics \& Society, [s.I.], v. 55, n. 2, p. 1-25, jun. 2013. RODRIGUES, Tania; IZMIRLIEVA, Milena; ANDO, Gustavo. Analysis of Brazilian Public Funding Process for New Biologic Drugs. Value in Health, vol. 16, no. 7, 2013.

SARKIN, Jeremy. Health. South African Human Rights Yearbook, vol. 8, p. 101-103, 1998.

SCHAUER, Frederick. Thinking Like a Lawyer: A New Introduction to Legal Reasoning Cambridge: Harvard University Press, 2009. 
SCOTT, Craig; ALSTON, Philip. Adjudicating Constitutional Priorities in a Transnational Context: A Comment on Soobramoney's Legacy and Grootboom's Promise. South African Journal on Human Rights, vol. 16, 2000.

SELEOANE, Mandla. Socio-Economic Rights in South Africa: Theory and Practice Pretoria: Human Sciences Research Council, 2001.

SILVA, Caitia Aida. Brazilian Prosecutors and the Collective Demands: Bringing Social Issues to the Courts of Justice. Miami: Latin American Studies Association Annual Meeting, 2000.

SILVA, Virgílio Afonso da. Deciding without Deliberating. International Journal of Constitutional Law, vol. 11, no. 3, p. 557-584, 2013.

SILVA, Virgilio Afonso da; TERRAZAS, Fernanda Vargas. Claiming the Right to Health in Brazilian Courts: The Exclusion of the Already Excluded? Law \& Social Inquiry, vol. 36, no. 4, p. 825-853, 2011.

SPAULL, Nicholas. South Africa's Education Crisis: The Quality of Education in South Africa 19942011. Johannesburg: Centre for Development and Enterprise, 2013.

THELEN, Kathleen. Historical Institutionalism in Comparative Politics. Annual Review of Political Science, vol. 2, p. 369-404, 1999.

TRAVASSOS, Denise Vieira; FERREIRA, Raquel Conceição; VARGAS, Andréa Maria Duarte; MOURA, Rosa Núbia Vieira de; CONCEIÇÃO, Elza Maria de Araújo; MARQUES, Daniela de Freitas; FERREIRA, Efigênia Ferreira e. Judicialização da Saúde: Um Estudo de Caso de Três Tribunais Brasileiros. Ciência \& Saúde Coletiva, v. 18, no. 11, p. 3419-3429. 2013.

UNITED KINGDOM. Foreign Office. British and Foreign State Papers. Vol. 16. London: James Ridgway, 1828-1829.

VALLE, Vanice Regina Lírio do. Judicial adjudication in housing rights in Brazil and Colombia: a comparative perspective. Revista de Investigações Constitucionais, Curitiba, vol. 1, n. 2, p. 67102, maio/ago. 2014. DOI: http://dx.doi.org/10.5380/rinc.v1i2.40511.

VIEIRA, Fabiola Sulpino; ZUCCHI, Paola. Distortions to National Drug Policy Caused by Lawsuits in Brazil. Revista de Saúde Pública, vol. 41, no. 2, 2007.

VIERA, Oscar Vilhena. Judicial Experimentation and Public Policy: A New Approach to the Right to Education in Brazil. OxHRH Blog, 31 July 2014. Available at: <http://ohrh.law.ox.ac.uk/?p=12688>.

WACKS, Raymond. Judges and Injustice. South African Law Journal, vol. 101, 1984.

WANG, Daniel W. Liang; FERRAZ, Octavio Luiz Motta. Reaching Out to the Needy? Access to Justice and Public Attorneys' Role in Right to Health Litigation in the City of São Paulo. SUR - International Journal on Human Rights, vol. 10, no. 18, June 2013. 
WANG, Daniel. Courts as Healthcare Policy-Makers: The Problem, the Responses to the Problem and Problems in the Responses. Direito FGV Research Paper Series, São Paulo, Paper n. 75.

WHITTINGTON, Keith E. Once More Unto the Breach: PostBehavioralist Approaches to Judicial Politics. Law \& Social Inquiry, vol. 25, no. 2, p. 601-634, Apr. 2000.

WILSON, Stuart; CLARK, Michael. Evictions and Alternative Accommodation in South Africa 2000-2016: An Analysis of the Jurisprudence and Implications for Local Government. 2. ed. Johannesburg: Socio-Economic Rights Institute of South Africa, 2016. 